Doctoral School of Interdisciplinary Medicine

\title{
Reproductive health information, behaviour and sexual education of adolescent girls in Hungary
}

\section{PhD Thesis}

Andrea Varga-Tóth MD

Supervisor:

Edit Paulik MD, PhD

Department of Public Health

Faculty of Medicine

University of Szeged

Szeged, 2018 


\section{LIST OF PUBLICATIONS}

\section{Publications related to the Thesis}

I. Varga-Tóth, A., Németh, G., Paulik, E. (2019). Szexuális nevelésről orvosi szemmel a hazai adatok és a nemzetközi irányelvek tükrében. Orvosi Hetilap (In press)

II. Varga-Tóth, A., Maróti-Nagy, Á., Németh, G., Paulik, E. (2017). Menarche as a predictor of risk-taking behavior in a sample of Hungarian adolescent girls. International Journal of Adolescent Medicine and Health, 0(0), pp. Published Online: 2017-05-24 | DOI: https://doi.org/10.1515/ijamh-2016-0135

III. Varga-Tóth, A., Paulik, E. (2015). Role of gynecologists in reproductive education of adolescent girls in Hungary. Journal of Obstetrics and Gynaecology Research, 41, 747754. doi: 10.1111/jog.12629.

IV. Varga-Tóth, A., Paulik, E. (2011). A méhnyakrák elleni védőoltás és a szürés jelentősen csökkenti a halálozást. Védőnő, 21:(6), 41-42.

\section{Abstracts related to the Thesis}

Varga-Tóth, A., Németh, G., Paulik, E. A gyermeknőgyógyászat kihívásai napjainkban. A Magyar Gyermeknőgyógyász Társaság XXXVIII. Kongresszusa. Gyula, 2018. 11. 09. Programfüzet absztraktokkal, pp. 15-16. http://crmedia.hu/congress/a-magyar-gyermeknogyogyasz-tarsasagxxxviii-kongresszusa/

Varga-Tóth, A., Németh, G., Paulik, E. (2018). Adolescent girls need for improved sexual education in Hungary. In: Book of Abstracts: The 15th Congress of the European Society of Contraception and Reproductive Health, The European Journal of Contraception \& Reproductive Health Care, 23:sup1, 1-143, DOI: 10.1080/13625187.2018. p. 49. Budapest, 2018. 05.09-2018.05.12.

Maróti-Nagy Á, Varga-Tóth A, Paulik E. (2015). Onset of the period and its effects on sexual and smoking behaviour of adolescents. In: Department of Public Health Faculty of Medicine University of Szeged (szerk.): 17th Danube-Kris-Mures-Tisa (DKMT) Euroregional Conference on Environment and Health: Program and Abstracts. (ISBN: 978-963-306-374-3) p. 59. Szeged, 2015. 06.05-2015.06.06.

Varga-Tóth, A., Paulik, E. (2011). Serdülőkorú lányok méhnyak szüréssel kapcsolatos ismeretei. In: Magyar Gyermeknőgyógyász Társaság XXXI. Kongresszusa. Programfüzet. p. E-12. Gyula, 2011.05.13-2011.05.14.

Varga-Tóth, A., Paulik, E. (2011). Misconceptions about human papillomavirus in a sample of Hungarian adolescent girls. Journal of Epidemiology and Community Health, 65:(Suppl. 1), A467.

Varga-Tóth, A., Paulik, E. (2009). Serdülőkorúak fogamzásgátlása és a hozzákapcsolódó jogi és etikai vonatkozások. In: Fiatal Nőorvosok V. Kongresszusa. Programfüzet, pp. 9-10. Balatonfüred, 2009.11.12-2009.11.14. 


\section{Table of Content}

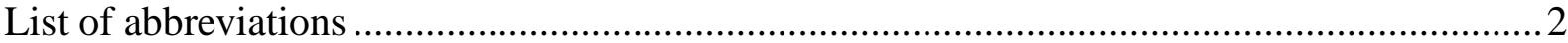

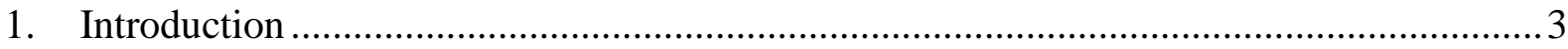

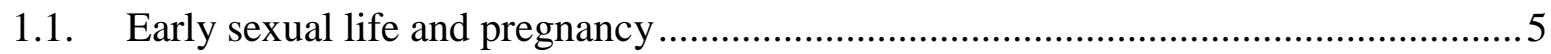

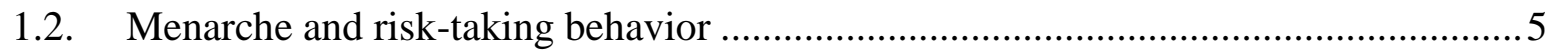

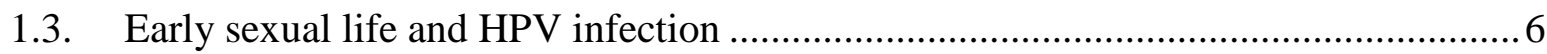

1.4. Cervical cancer prevention, gynecological examination ..................................... 10

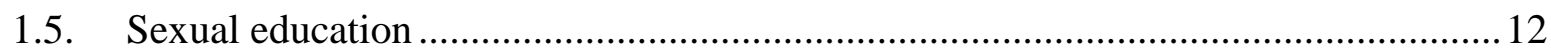

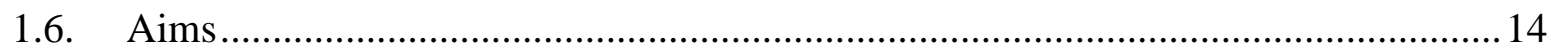

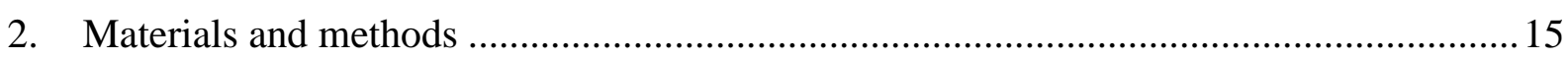

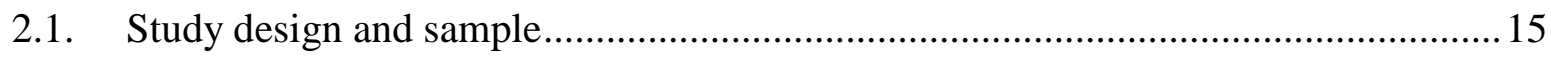

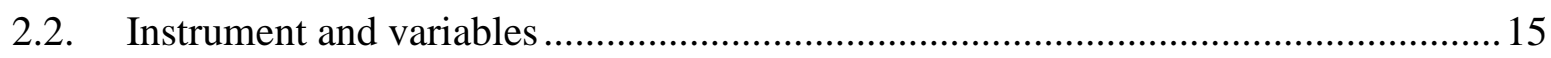

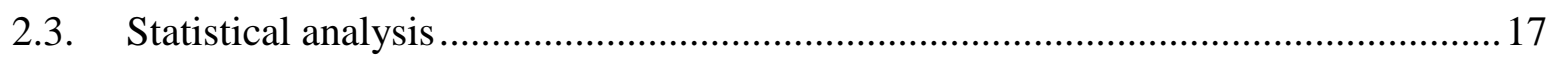

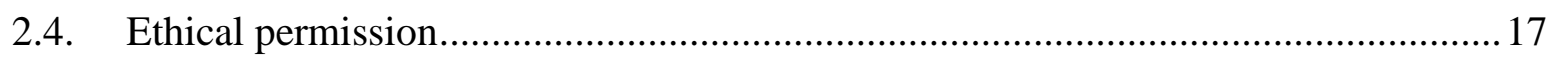

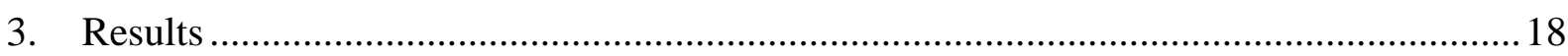

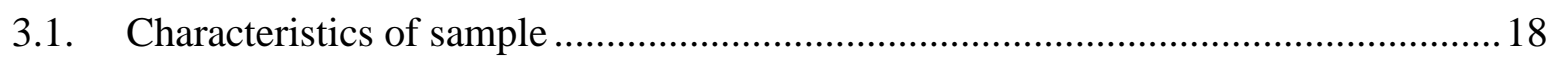

3.2. Menarche as a predictor of risk-taking behaviour ................................................ 18

3.3. Visiting gynecologist and sexual knowledge..................................................... 24

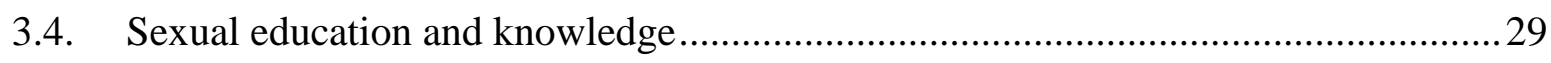

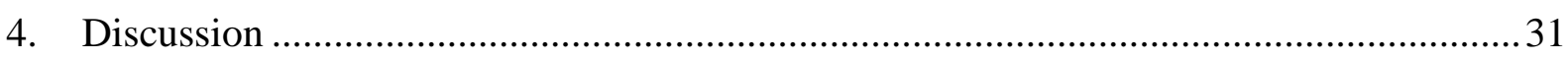

4.1. Menarche as a predictor of risk-taking behaviour ............................................ 31

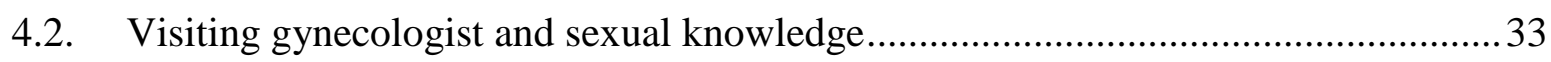

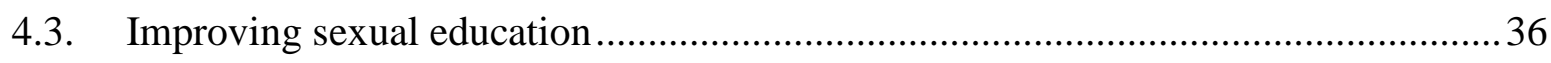

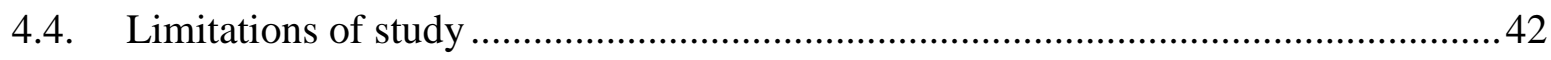

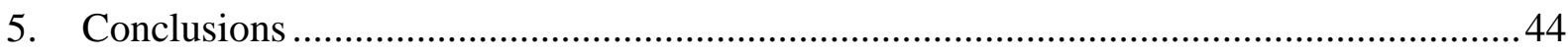

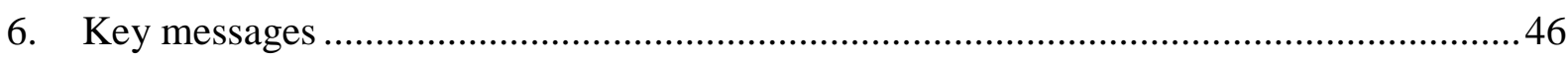

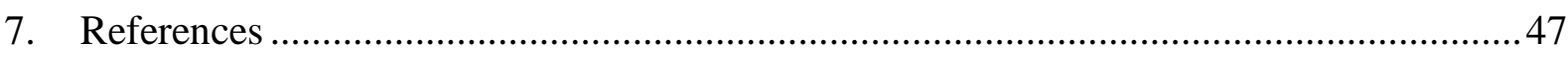

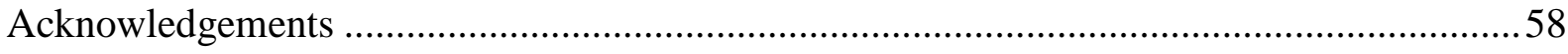

APPENDICES 


\section{List of abbreviations}

$\begin{array}{ll}\text { AAP } & \text { American Academy of Pediatrics } \\ \text { ACOG } & \text { American College of Obstetricians and Gynecologists } \\ \text { ASO4 } & \text { Adjuvant System 04 } \\ \text { CA } & \text { Committee on Adolescence } \\ \text { CI } & \text { confidence interval } \\ \text { CIN } & \text { cervical intraepithelial neoplasia } \\ \text { CSE } & \text { comprehensive sexuality education } \\ \text { DMPA } & \text { depomedroxyprogesterone acetate } \\ \text { DNA } & \text { deoxyribonucleic acid } \\ \text { EMMI } & \text { Emberi Eröforrások Minisztériuma (Ministry of Human Resources) } \\ \text { EU } & \text { European Union } \\ \text { FDA } & \text { Food and Drug Administration } \\ \text { GP } & \text { general practitioner } \\ \text { HBSC } & \text { Health Behaviour of School-aged Children } \\ \text { HPV } & \text { human papillomavirus } \\ \text { IARC } & \text { International Agency for Research on Cancer } \\ \text { IPPF } & \text { International Planned Parenthood Federation } \\ \text { IUD } & \text { intrauterine device } \\ \text { IUS } & \text { intrauterine system } \\ \text { KSH } & \text { Központi Statisztikai Hivatal (Central Statistical Office) } \\ \text { LARC } & \text { long-acting reversible contraception } \\ \text { LNG } & \text { levonorgestrel } \\ \text { LNG-IUS } & \text { levonorgestrel-releasing intrauterine system } \\ \text { OECD } & \text { Organization for Economic Co-operation and Development } \\ \text { OEK } & \text { Országos Epidemiológiai Központ (National Epidemiological Centre) } \\ \text { OR } & \text { odds ratio } \\ \text { QALY } & \text { quality-adjusted life-years } \\ \text { SAHM } & \text { Society for Adolescent Health and Medicine } \\ \text { SD } & \text { standard deviation } \\ \text { SPSS } & \text { Statistical Package for the Social Sciences } \\ \text { SRHR } & \text { Sexual and Reproductive Health and Rights } \\ \text { STI } & \text { Sexually Transmitted Infection } \\ \text { SZTE } & \text { Szegedi Tudományegyetem (University of Szeged) } \\ \text { UNESCO } & \text { United Nations Educational, Scientific and Cultural Organization } \\ \text { WHO } & \text { World Health Organization } \\ & \end{array}$




\section{Introduction}

Today, a significant number of adolescents around the globe are sexually active, and this proportion increases steadily from mid- to late adolescence (Chandra-Mouli, 2014). Sexual life that is started at an ever-increasingly younger age among teenagers is a striking tendency in the majority of the developed countries of the world.

In the international study of school-aged children (Health Behaviour of School-aged Children, HBSC), which also involved Hungary, the proportion of 15-year-olds who have had sexual intercourse (Table 1) was 27\% in 2005/2006 (Currie, et al., 2008), 26\% in 2009/2010 (Currie, et al., 2012) and 21\% in 2013/2014 (Inchley, et al., 2016). Boys were more likely to report having sexual intercourse in around half of the countries, so the average prevalence rates were the followings: $30 \%$ among boys, $24 \%$ among girls in 2005/2006, $29 \%$ among boys, $23 \%$ among girls in 2009/2010, and 24\% among boys, 17\% among girls in 2013/2014 (Currie, et al., 2008; Currie, et al., 2012; Inchley, et al., 2016). Experience of sexual intercourse among 15year-old adolescents varies across countries; according to the HBSC surveys the higher rates for girls were found in Northern Europe, and relatively low rates were reported in Southern and Western Europe. The highest rate of girls was found in Greenland; it was $66 \%$ according to the HBSC 2005/2006, 71\% according to the 2009/2010 survey (Currie, et al., 2008; Currie, et al., 2012; Sieving, et al., 2002). In 2013/2014 the highest prevalence was registered in Bulgaria (21\%; in 2005/2006 the rate was $31 \%$ ), although in this year no data was available about Greenland, because Greenland (and Norway) excluded items on sensitive topics such as sexual health (Inchley, et al., 2016).

According to the Hungarian data of the HBSC 2006, an average of $27.9 \%(30.1 \%$ of boys, $25.8 \%$ of girls) of 9th-grade (15-year-old) adolescents admitted to having experienced some sexual contact (Várnai \& Németh, 2007) (Table 1). According to the HBSC 2010, an average of $27.7 \%$ (32.8\% of boys, $22.2 \%$ of girls) of 9th-grade adolescents have had some sexual contact (Table 1). In total, $57.1 \%$ of the sexually active 9 th-grade youngsters were 14 years old or younger at the start of their sexual life; $60.7 \%$ of sexually active 15 years old boys and $51.4 \%$ of girls have started their sexual life at the age of 14 or earlier (Költö, 2011). A growing proportion of young people start their sexual life quite early. According to the data of HBSC 2014 study, these proportions among the Hungarian students are higher than the HBSC average, especially in case of girls (26\% vs. $17 \%$ ), rather than in case of boys (34\% vs. $24 \%$ ) 
(Inchley, et al., 2016; Költő, 2016). It should also be emphasised that among the 15-year-old students $48.8 \%$ of sexually active boys and $40.6 \%$ of sexually active girls have started sexual life at the age of 14 or younger (Költö, 2016). The most commonly used method for protected sexual intercourse among sexually active students was condom - alone or combined with other methods -, however $14.2 \%$ of students have never used any protection methods (Költö, 2016). By comparing this with previous data - in 2006 this proportion was only $7.3 \%$, and $10.2 \%$ in 2010 - it shows an unfavourable picture, since the proportion of those who do not use any kind of protection is not merely high but shows an increasing tendency in Hungary.

Table 1 Characteristics of sexual behaviour among 15-year-old adolescents according to international and Hungarian data of HBSC surveys (\%)

\begin{tabular}{lccccc}
\hline \multirow{2}{*}{$\begin{array}{l}\text { Timeperiod of } \\
\text { surveys }\end{array}$} & \multicolumn{3}{c}{ The proportion of 15-year-olds who have had sexual intercourse (\%) } \\
\cline { 2 - 6 } & Boys & Girls & Total & Boys & Girls \\
\cline { 2 - 6 } & 30.0 & 24.0 & 27.0 & 30.1 & 25.8 \\
\hline $\mathbf{2 0 0 5 / 2 0 0 6}$ & $\mathbf{1 , 2}$ & 23.0 & 26.0 & 32.8 & 22.2 \\
\hline $\mathbf{2 0 0 9 / 2 0 1 0}$ & 29.0 & 17.0 & 21.0 & 34.0 & 26.0 \\
\hline $\mathbf{2 0 1 3 / 2 0 1 4}$ & 24.0 & & & & \\
\hline
\end{tabular}

Sources: ${ }^{1}$ Currie et al., 2008; ${ }^{2}$ Várnai \& Németh, 2007; ${ }^{3}$ Currie et al., 2012; ${ }^{4}$ Költő, 2011; ${ }^{5}$ Inchley et al., 2016; ${ }^{6}$ Költö, 2016

Sexuality in young ages and the prevention of related unwanted consequences pregnancy, infectious diseases, etc. - means a worldwide problem, the solution of which requires multisectorial (health care, education, family, etc.) approach, since only those adolescents are able to make responsible decisions about their sexual life who receive proper sexual education. 


\subsection{Early sexual life and pregnancy}

In connection with early sexual life, the proportion of unwanted pregnancies is predominantly high in Eastern Europe, including Hungary (Sedgh, et al., 2007, Sedgh, et al., 2015). Consequences of early sexual life among Hungarian adolescents are also reflected in demographic data. According to the study of Sedgh et al. (2015) involving 21 countries, based on the data of the year 2011, pregnancy rates were the highest among the 10-14-year-old girls in Hungary: 1.19 pregnancies per 1000 females in this age group, 60\% of which ended in induced abortion; and 38 pregnancies were reported per 1000 15-19-year-olds, with 41\% abortion rate (Sedgh, et al., 2015). The number of pregnancies and abortions among adolescents aged $\leq 19$ years is still high in Hungary. In 2011, more than 5000 live births and almost the same number of abortions were registered in this age group in Hungary (Központi Statisztikai Hivatal [KSH], 2012). According to the data of the Central Statistical Office of Hungary (KSH) in 2016, there is a decreasing tendency of teenage abortions, however one third of more than 10000 pregnancies were registered in the age group of 19 years and younger (63.4\% among 10-14year-olds, 36.2\% among 15-19-year-olds) ended in abortion (KSH, 2017a; KSH, 2017b, KSH, 2018).

\subsection{Menarche and risk-taking behavior}

Hungary belongs to the economically developed part of the world. Due to the higher socioeconomic status and the better nutrition of the people, the secular trends of the decreasing age at menarche can be observed here as well, as in many other industrialized countries (Chodick, et al., 2005; Tekgül, et al., 2014; Wattigney, et al., 1999). While in the year 1891 the onset of menarche was at the age of 15.33 years (Doktor, 1891 cited by Bodzsár, 2000), by the end of the 20th century, it had decreased to 12.58 years (Bodzsár, 1977; Bodzsár \& Zsákai, 2002).

Paralell with the decreasing age of menarche, the age of adolescents at the time of their first sexual intercourse is declining in the developed countries (Wellings, et al., 2006). Early sexual life is related to the higher risk of sexually transmitted diseases (STIs) and unwanted pregnancies; the number of STIs among adolescent girls is genereally increasing (Godeau, 2011). In Hungary, the rates of 15 -year-old girls and boys who had had sexual intercourse 
according to the 2013/2014 report of the HBSC were higher than the HBSC average (Table 1) (Inchley, et al., 2016; Költő, 2016).

Another risk behavior among adolescents is tobacco use. Smoking is related to other risk behaviors and negative health outcomes, as well as early sexual activity (Godeau, et al., 2008). Among 15-year-old Hungarian adolescent girls, $26.4 \%$ of them smoke at least once a week according to HBSC 2006 (Kovacsics, et al., 2007), 26\% according to HBSC 2010 (Halmai $\&$ Németh, 2011), while the next survey (2014) showed 20.2\% (Arnold, 2016).

Among adolescents, gender differences have disappeared in the past years (in 2006 $26.6 \%$ among boys/26.4\% among girls, in $201029.6 \%$ among boys/26.0\% among girls, in 2014 $20.2 \%$ in both) the prevalence of smoking in adolescent girls has shown a growing and then a decreasing tendency (Currie, et al., 2008; Currie, et al., 2012; Inchley, et al., 2016).

Several studies have shown a connection between age at menarche and risk behavior among adolescents. Gaudineau et al. (2010) found that girls who experienced early menarche were more likely to engage in risk behaviours such as alcohol abuse and early sexual initation. Downing and Bellis (2009) explored that early puberty should be a potential factor influencing adolescent behaviour especially in deprived communities. The findings of Boden et al. (2011) suggested that earlier age of menarche was associated with increased risk of earlier sexual involvement, and its adverse consequences including early pregnancy and exposure to sexually transmitted infections (STIs).

\subsection{Early sexual life and HPV infection}

The oncogenic potential of HPV has been officially acknowledged since 1995 (World Health Organization International Agency for Research on Cancer [WHO IARC], 1995, WHO IARC, 2007). Considering the oncogenicity, there are low and high-risk HPV types; $93.5 \%$ of tumours caused by HPV is cervical cancer, for the development of which high risk HPV types (e.g. 16, $18,31,33,45)$ are responsible. Low risk HPV types 6 and 11 are responsible for the formation of genital warts, which rarely turn into a malignant form.

HPV infection is a special process. The virus enters the body through minor injuries of the epithelium, multiplies within the host cell, remains in the epithelium, and integrates into the DNA of basal cells. Since the infection is local, there is no viraemia and inflammation, the immune system is not strongly triggered, the exposure is weak for the antigen presenting cells, 
the level of antibodies stays low and therefore the infection will be hidden from the immune system. As a consequence of this, the immune system of a woman with a previous HPV infection will not be able to recognize a subsequent potential infection, so it is possible to have reinfections during the whole life. HPV can be transmitted by any form of sexual contact, even with skin-to-skin contact, therefore transmission can not be completely prevented by the use of condom (Fülöp, 2010; Hernandez, et al., 2008; Pete, 2011). The importance of being familiar with the main ways of transmission is unquestionable, because the primary risk factor for developing HPV-related oropharyngeal squamous cell carcinoma is oral HPV-infection and the majority of oral HPV-infections are acquired by oral sex (Taberna, et al., 2017).

With the tendency of having the first sexual act at a younger age, the risk of being exposed to HPV infection is also increasing. Nowadays this is considered to be the most common sexually transmitted viral infection affecting about $80 \%$ of sexually active females at least once in their lifetime. Fortunately, the virus disappears spontaneously in $90 \%$ of these females within 3-6 months. However, the carcinogenic HPV infection can exist for longer times (even for 12-36 months) in 10\% of females, which means a higher risk for the development of cervical cancer (Bano, et al., 2008; Sigurdsson \& Sigvaldason, 2007).

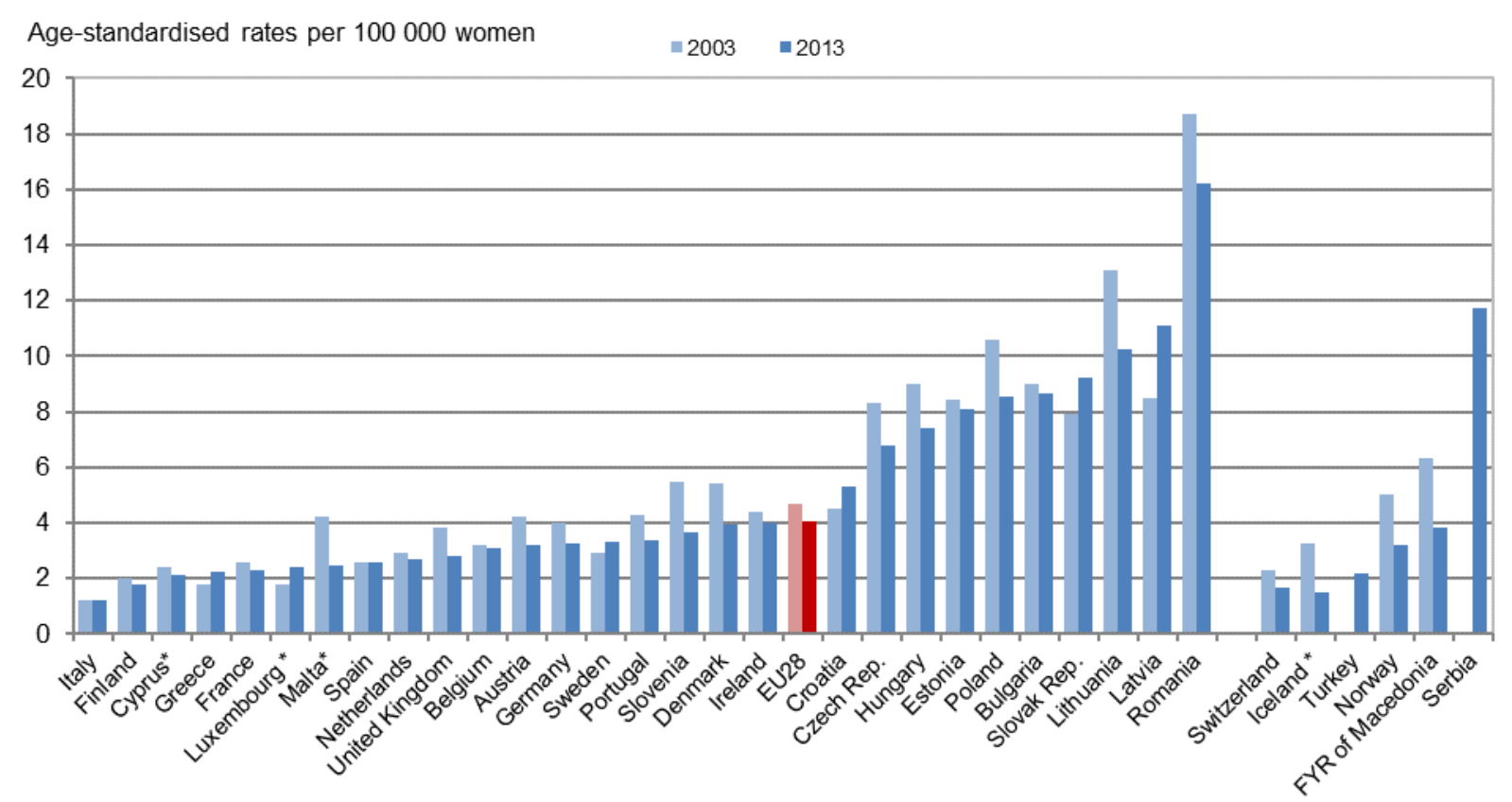

Figure 1 Cervical cancer mortality, 2003 and 2013 (or nearest years)

Source: OECD/EU, 2016, p. 137. 
In Europe, cervical cancer is a common malignant tumour in women younger than 45 . Although, the mortality rates for cervical cancer declined across European Union (EU) countries between 2003 and 2013 (Figure 1), Hungary's situation is unfavorable as compared to other EU countries in relation to cervical cancer mortality: the mortality rate was $7.4 / 100,000$ women in Hungary, while the EU-28 average was 4.0/100,000 women in 2013 (OECD/EU, 2016).

As it was mentioned, the risk of cervical cancer is increased by the HPV infection. The awareness of HPV associated diseases and HPV vaccination plays an important role in the prevention.

The aim of HPV vaccination is to counteract the entry of the virus into the host cell by the help of antibodies formed in the vaccinated person. The application of vaccines made by recombinant DNA technology is safe, since protection develops without the initiation of the disease. The aim is to establish a long-term protection, to maintain permanently high antibody levels and to induce an immune response which is stronger than that would be initiated by a natural infection. High serum antibody levels can transude into the cervico-vaginal mucosa to the place of potential infection - ensuring a long-term protection. The genetic difference among the various HPV types is minimal, therefore besides the protection developed for the certain HPV types, cross protection can also develop for similar types (Dawar, et al., 2007; Fülöp, 2010; Pete, 2011).

Currently three types of HPV vaccines are available worldwide. The bivalent vaccine has been developed for HPV types 16 and 18 and contains the Adjuvant System 04 (AS04), which is responsible for its outstanding immunogenecity (Garçon, et al., 2011). During the 9 year follow up permanently high HPV 16/18 antibody levels were registered. Moreover, significant cross protection for types $31,33,39,45$ and 51 was also proven. In the study group free of HPV at enrolment application of the vaccine could decrease the occurrence of CIN3 (cervical intraepithelial neoplasia) stage (the last precancerous stage before cervical cancer would develop) by 93\% regardless of the oncogenic HPV type (Schauner \& Lyon, 2010; Pete, 2011). Kavanagh et al. (2017) confirmed an initially unanticipated benefit of the bivalent vaccine: clinically important cross-protection against three further oncogenic HPV types (31, 33 , and 45$)$, detected in approximately $13 \%$ of cervical cancers globally.

A quadrivalent vaccine for HPV types 6, 11, 16, and 18 (HPV 6/11/16/18) has been developed for prevention of cervical cancer, genital warts, and vulvar and vaginal precancerous 
lesions. Prophylactic vaccination of young women was 96\%-100\% effective in preventing HPV 6/11/16/18-related cervical and anogenital precancers and genital warts (Gellin, et al., 2007). The quadrivalent vaccine may have an advantage over the bivalent vaccine in reducing healthcare costs and quality-adjusted life-years (QALYs) lost. The bivalent vaccine may have an advantage in preventing death due to cancer. However, considerable uncertainty remains about the differential benefit of the two vaccines (Jit, et al., 2011).

The new 9-valent HPV vaccine was developed to increase protection against 5 more strains (e.g., HPV types 31, 33, 45, 52, and 58). This vaccine has the potential to offer protection against approximately $90 \%$ of cervical cancers (Yang \& Bracken, 2016).

In the 11 years since their first licensure, the HPV vaccines have been distributed globally in over 270 million doses and are demonstrably safe in population usage. The vaccines are remarkably effective in real-world prevention of targeted type HPV infection and highgrade CIN (Brotherton, 2017).

The role of vaccines is prevention and not the treatment of an existing condition. Every girl/woman above the age of 9-10 can be vaccinated. It has also been proven in studies that vaccination is still useful after the initiation of sexual life. A negative cytology result of sexually active females is necessary before vaccination, but HPV genotyping is not a requirement (Dawar, et al., 2007; Pete, 2011).

Prophylactic HPV vaccines are commercially available worldwide. Although Cervarix is the most cost effective vaccine with proven efficacy in one dose, the WHO recommends two doses for either Gardasil 9 or Cervarix for those up to 15 years of age, and three doses for women 15 years or older (Harper \& DeMars, 2017).

In Hungary, girls from the age of 12 can receive HPV vaccination free of charge since 2014 (till 2018 Cervarix, from 2019 Gardasil 9). HPV vaccinations are organised and carried out in the framework of school based vaccination programs. Task of the school health service involves the information of parents/guardian and girls entitled for vaccination about the opportunity and time of the voluntary, free HPV vaccination. The vaccination is voluntary, and the parent/guardian has to make a statement about the claim for the vaccine (Emberi Erőforrások Minisztériuma [EMMI], 2018). According to the report of the National Epidemiological Centre the vaccination coverage was around or over $75 \%$ in the last years at country level, although there are differences by counties (Országos Epidemiológiai Központ [OEK], 2015; OEK, 2016). 


\subsection{Cervical cancer prevention, gynecological examination}

Morbidity and mortality data of cervical cancer in Hungary reflect the lack of knowledge regarding sexuality, and subsequent consequences of improper health behaviour and attitude. In 2014, according to the National Cancer Registry, 1161 new cervical cancer cases were registered in Hungary (KSH, 2017b). Compared to developed countries, mortality is also very high in Hungary; in 2016 the number of women who died because of cervical cancer was 396, i.e. this was the number of death caused by a disease, which could have been prevented and in case of early recognition - treated (KSH, 2017a). Moreover, in Hungary the participation in screening aimed at an early recognition of cervical cancer is among the lowest in the OECD (Organization for Economic Co-operation and Development) countries, a tendency shared by the other Eastern European countries (OECD, 2009; OECD/EU, 2016; Todorova, et al., 2009). According to data of the year 2014, participation rates (35.9\%) on screening aiming the early recognition of cervical cancer were far behind the average of the European Union $(63.0 \%)$ among women in the age group of 20-69 (OECD/EU, 2016).

Today, it is well established that infection with high oncogenic risk HPV types is the main causal factor in cervical cancer (WHO IARC, 1995; WHO IARC, 2007). The risk of HPV infection is increased by sexual activity, namely number of sexual partners and younger age at first intercourse. However, not all infections with high risk HPVs persist or progress to cervical cancer, thus suggesting that, although HPV infection is necessary, but it is not sufficient to induce this disease. Other factors, such as smoking (Castle, 2008; Fang, et al., 2018), parity (Jensen, et al., 2012), use of oral contraceptives, diets deficient in vitamins A and C, and genetic susceptibility traits are also involved (Knobler, et al., 2004). There is a long time period (years or decades) from the persistant HPV infection till the manifestation of cervical cancer.

Precancerous stages are defined according to the following CIN levels:

- CIN1: abnormal cells are present in the lower (basal) region (involving about onethird) of the epithelium;

- CIN2: about two-thirds of the epithelial (lower and middle) layer are affected;

- CIN3: abnormal cells are also present in the upper (superficial) layer of the epithelium, but the basal membrane is intact.

CIN stages can persist for years without any change, but regression or progression to a more severe stage are also possible. According to literature data, the chance for regression in 
case of CIN1 is $80 \%$, for CIN2 it is $40 \%$. There are limited data about CIN3, but it can be stated that most cases progress into cancer, though some of them can regress or remain unchanged for years (Bősze, 2010).

Prevention of cervical cancer consists of two parts: primary prevention means education and vaccination, while secondary prevention involves gynecological cancer screening (oncocytology and colposcopy of the cervix), and in case of its necessity, minor surgical procedures as well.

There are differences among the public health and clinical recommendations for cervical cancer screening according to target groups and frequency of screening. According to the recommendations for organised public health screening women aged 25-65 years - in case of one negative screening result - should participate on screening (involving cytology testing) every 3 years (Kovács, et al., 2007). This recommendation, however, does not make the clinical principle questionable, which is accepted by professionals in Hungary and which emphasises the necessity of the annual clinical examination of sexually active females regardless of their age.

Although the national screening program for cervical cancer was launched in Hungary in 2003, it did not alter the situation significantly. Boncz et al. established that although after launching the organized screening, values of the annual and 3-year participation in the group aged 25-64 years improved as compared to that of former years, the measure of screening is still low (between 2003 and 2005, the annual participation was 23.4-24.3\%, and the 3-year participation was 52.6\%), while the mortality rate is invariably high (Boncz, et al., 2007). In 2008 a pilot cervical cancer screening program involving health visitors was started to improve the participation rate in Hungary; this program has been widening during the last years (Vajda, et al., 2017a). The invitation rate was $32.45 \%$, and the compliance rate was $8.26 \%$ at country level according to the analysis of data between 2013 October and 2015 September in Hungary (Vajda, et al., 2017b). Factors contributing to the low level of participation might be the lack of a national screening program, opportunistic characteristics of the screening and the short comings of the health-conscious attitude. 


\subsection{Sexual education}

Hungarian studies of sexual education and knowledge (Devosa, et al., 2016; Semsey, 2016; Varga-Tóth \& Paulik, 2015) point out that even though young people/adolescents have some knowledge of sexual life, neither the quantity, nor the quality (content and form of education) of this knowledge fit the expectations. It is also typical in this age group that physical maturity does not always equals to psychic maturity, which can be more risky when it is associated with the lack of knowledge regarding sexuality. Unprotected sexual life initiated at the age of 14 or younger has an impact on subsequent health behaviour as well (Fergus, et al. 2007; Poulin \& Graham, 2001).

Education delivering knowledge of sexuality has a deterministic effect on the prevention of unwanted pregnancies and tumours. Although several methods of sexual education exist currently in Hungary, their effectiveness is questionable. The main source of knowledge regarding sexuality is the parent, followed by the health visitor, friends and teachers; however only every 5th girl received information from a physician (GP, gynecologist, etc.) (Varga-Tóth \& Paulik, 2015).

By reviewing the history of sexual education it can be seen that Hungary is lagging behind the European countries. During the period from after the 2nd World War until the beginning of the 1970s health education mostly involved enlightenment only and was focusing on topics regarding personal hygiene. After that, in accordance with the current demographic policies, teachers were obliged to introduce "family life education" classes in the final years of primary school. Teachers were, however, given no help and fulfilment of the task was also not controlled, but first biology textbooks including anatomical knowledge were published (Simich, 2010).

Though ethical education, which goes into details in the topic of smoking, alcohol and drug use, is involved in the current primary school curriculum, sexuality and sexual life are only discussed in a limited amount. The National Core Curriculum, which regulates education and is currently in force in Hungary, identified family life education as a field for development: "Therefore, disseminating patterns of harmonious family life and promoting the appreciation of family communities is among the principal tasks of public education institutions. Preparation for family life helps children and young persons establish responsible partner relationships and disseminates knowledge about handling the conflicts that may emerge in family life. School 
education must also address issues of sexual culture.” (110/2012. Korm. rendelet, 2012, p. 10642). In the framework of science education in grades 5-6, and of biology education in grades 7-8 "reproduction, ontogenesis and sexuality" are named as topics, however teachers can decide about the exact content of education, curriculum, applied method and form of examination (110/2012. Korm. rendelet, 2012).

In Europe, compulsory sexual education in school was first introduced in 1955 in Sweden, followed by Germany, Austria, the Netherlands and Switzerland in the following decades. By the turn of the millennium, other countries of the European Union joined as well; even the religious Ireland in 2003 (Loeber, et al., 2010).

If the problem is discussed from the viewpoint of health/medical sciences, it can be stated that those professionals (psychologists, gynecologists, pediatric gynecologists, dermatologists) let their voice be heard in relation to the urgent necessity of psycho sexual education, who meet the most young patients in trouble. It would be necessary to introduce not only type 2 sexual education, which shows the dark side (unwanted pregnancy, abortion, sexually transmitted diseases, consecutive infertility, etc.), but also a holistic (type 3 sexual education) approach, which helps the acquisition of inner harmony and responsible and conscious life skills (friendship, family, parental role) by the young people in a scientifically justified and age-appropriate way (American College of Obstetricians and Gynecologists [ACOG], 2016). 


\subsection{Aims}

In our study sexual activity of adolescent girls, their knowledge related to contraception and sexually transmitted infectious diseases, and gynecological (examination, cancer screening, etc.) experiences were measured before sexual education performed by a gynecologist.

This study aimed to assess

- the relationship between menarche and some socio-demographic parameters, sexual activity and tobacco smoking in a sample of Hungarian adolescent girls;

- the knowledge about sexually transmitted infection such as HPV infection and its prevention among adolescent girls;

- the knowledge about cervical cancer screening and the factors influencing it;

- whether sociodemographic characteristics of adolescent girls, their knowledge about cervical cancer screening, and their sexual activity are associated with whether or not they have visited a gynecologist.

Finally, our aim was to determine the way of sexual education of young people provided by physicians - GPs, pediatricians, obstetrician-gynecologists etc. - in accordance with the results of the questionnaire-based study, the experiences gained during the interactive education and the recommendations of related international guidelines. 


\section{Materials and methods}

\subsection{Study design and sample}

Self-administered (paper and pencil) questionnaire-based study was carried out at the Pediatric Gynecology Centre of the Department of Obstetrics and Gynecology, University of Szeged, Hungary, among participants of professional sexual education, held by a pediatric and adolescent gynecologist. Convenience sampling was based on the availability of participants; they were 13-18-year-old girls attending primary or secondary school. The survey was carried out from spring 2009 to spring 2010, the second wave was in 2013, and the third in 2016. Within the study period, all eligible young girls were offered the questionnaire before the education; altogether 868 girls were involved. The participation was voluntary and anonimous.

\subsection{Instrument and variables}

The questionnaire comprised sociodemographic characteristics, risk behaviour (sexual activity, smoking), onset and parameters of their periods, knowledge about contraceptive methods, cervical cancer screening, and HPV infection, sources of information, and the visits to the gynecologist.

The survey items were evaluated in a pilot study with the participation of 20 people from the targeted age group and performed the necessary adjustments in the questionnaire.

With regard to socio-demographic characteristics, age was measured in years on the basis of the date of birth.

The living place was defined in two categories: urban places were towns and rural places involved villages and farms.

Educational level of the parents (mother and father) was classified into three groups on the basis of their highest qualification: elementary ( 8 years of schooling or less), secondary (912 years of schooling) and higher (more than 12 years of schooling).

Self-estimate of the financial background of the family was done on a 5-degree scale, in one part of the evaluation only three categories (poor, average or good) were used.

The onset of the first period was measured in years according to the age of the adolescent girl at that time; because of the retrospective form of our study, we applied the recall method 
for assessing their age at menarche. The classification of age at menarche is variable in the literature. According to the age-classification used by Kaltiala-Heino et al. (2011) and Marino et al. (2013), three groups were formed: earlier, when the period began at age 11 or earlier; normative, when the period began at the age of 12-13; and later, in case the first period began at age 14 or later.

Among risk behaviors, participants were asked whether they smoke or not. In the case of regular tobacco use, the age of smoking the first cigarette was determined and also the number of cigarettes smoked per day.

Regarding sexuality, participants were asked about ever being sexually active (sexual activity). If they had sexual contact, the first occasion of sexual intercourse was obtained, along with the number of previous partners, the frequency of sexual intercourses, and contraception. In our study, sexual life that started before 18 years of age was considered as a risk behavior.

The frequency of visiting a doctor was established by the question, 'Have you consulted a gynecologist yet?', and if yes, 'What was the cause of visiting a doctor (contraception, menstrual disorders, etc.)?'

Six questions were included to measure the knowledge about the cervical screening process and its evaluation. There were two open-ended questions about how the screening test is done and the target population; the answers were assessed by a gynecologist. Four closed questions were related to the painful nature of screening, to its recommended frequency, to pathological findings (results of the Pap test) and to the screening as a preventive measure of cervical cancer. The answers were classified as 'correct'and 'incorrect'. The assessment of the answers was performed on the basis of definitions provided by current textbooks (Papp \& Csapó, 2009). Taking the correct answers into consideration, a 6-item score was developed where the higher the scores were, the better the level of knowledge turned out to be.

The study involved the assessment of knowledge of HPV transmission (kissing, petting, skin-to-skin contact of the genitals, etc.) and of the relationship between HPV and cervical cancer.

We also studied the familiarity with emergency contraception (e.g. when to take the pill).

The potential sources of the girls' sexual knowledge (parents, friends, teachers, nurses, physicians, books and the Internet) were asked about. More than one source was possible to be marked. 


\subsection{Statistical analysis}

Statistical analysis was carried out using SPSS 20.0 and 24.0 for Windows. We used simple descriptive statistics to describe the overall characteristics of the sample. Chi-square and oneway ANOVA tests were applied to perform bivariate comparisons. Chi-square tests were performed to compare the socio-demographic characteristics, sexual activity and smoking habits according to the timing of the period, and the risk behavior according to sociodemographic characteristics. One-way ANOVA was carried out to assess the differences in the age at first sexual intercourse, the number of sexual partners, age at the start of smoking, and the number of smoked cigarettes per day by menarche.

Multiple comparisons were done by multivariable logistic regression analysis:

- to assess the relationship between risk behavior (sexual activity and tobacco use) and socio-demographic characteristics, menarche, presence of other risk behaviors;

- to analyze the association between the visit to the gynecologist as a dependent variable and age, type of school, financial background and sexual activity as independent variables.

The determinations of the logistic regression model were based on the Hosmer-Lemeshow goodness-of-fit tests for each dependent variable. Odds ratios (OR) and 95\% confidence intervals $(\mathrm{CI})$ were also calculated for all variables.

Statistical significance was defined at $\mathrm{p}<0.05$ in all analyses.

\subsection{Ethical permission}

The study protocol was approved by the Regional and Institutional Human Medical Biological Research Ethics Committee of the University of Szeged (Ethical permission serial number: 2418). The study was done in accordance with the World Medical Association Declaration of Helsinki regarding ethical conduct of research involving human subjects. Informed written consent, including parental permission, was obtained from the study population prior to the beginning of the study. 


\section{Results}

\subsection{Characteristics of sample}

Finally, there were 868 participants in the study. Mostly girls from grades 7-8 and 9-10 were interested in sexual education, which was also reflected by the age composition of the participants: the proportion of 14-year-olds (27.4\%) and 15-year-olds (28.6\%) was dominant. The proportion of participants by school type was nearly identical: 261 students $(30.1 \%)$ attended primary school, 274 (31.6\%) secondary technical school and 333 (38.4\%) secondary grammar school.

More than one-third (35.3\%) of the participants have already had sexual contact, half $(51.3 \%)$ of the sexually active girls had their first sexual intercourse at the age of 15 or younger; $5.3 \%$ of girls at the age of 13 , and $18.1 \%$ at the age of 14 . In the biggest proportion (35.2\%), the age of 16 was indicated as the beginning of sexually active life; the average age of the first sexual contact was $15.35 \pm 1.12$ years (min. 13, max. 18). $22.3 \%$ of girls were regular smokers and the prevalence of smoking increased with age: it was $4.7 \%$ at the age of $13,17.4 \%$ at the age of 15 and $45 \%$ at the age of 18 .

The number of participants analysed in the next sections is different according to the purpose and the time of the evaluation.

\subsection{Menarche as a predictor of risk-taking behaviour}

In this analysis 655 girls were involved from the database of 2009 (seven participants were excluded because they had not as yet started having their periods at that time) (Table 2 and Table 3).

The mean age of the girls was $15.68 \pm 1.19$ years, and the mean age at first period was $12.47 \pm 1.11$ years. Most of them lived in a town (68.1\%), half of them claimed that their family's financial status was average (Table 2), $27.3 \%$ of them were regular smokers and $45.2 \%$ of them were sexually active (Table 3 ). 
Table 2. Socio-demographic characteristics of the sample $(\mathrm{N}=655)$

\begin{tabular}{lcc}
\hline Variables & n & \% \\
\hline Age (years) & 111 & 16.9 \\
14 & 208 & 31.8 \\
15 & 168 & 25.6 \\
16 & 108 & 16.5 \\
17 & 60 & 9.2 \\
18 & & \\
Education & 73 & 11.1 \\
Elementary & 582 & 88.9 \\
Secondary & & \\
\hline Mother's education & 64 & 9.8 \\
Elementary & 413 & 63.1 \\
Secondary & 177 & 27.1 \\
$\quad$ Higher & & \\
\hline Father's education & 55 & 8.5 \\
Elementary & 436 & 67.6 \\
Secondary & 154 & 23.9 \\
Higher & & \\
\hline Living place & 209 & 31.9 \\
Rural & 446 & 68.1 \\
Urban & 37 & 51.0 \\
\hline Financial status & 334 & 43.4 \\
Poor & 284 & \\
Average & & \\
Good & & \\
\hline
\end{tabular}

There were no significant differences according to the socio-demographic characteristics of the sample (living place, parents' education, and financial status) and the time of the first period (earlier, normative, and later) (Table 4). 
Table 3 Behavioural characteristics of the sample $(\mathrm{N}=655)$

\begin{tabular}{|c|c|c|}
\hline Variables & $\mathbf{n}$ & $\%$ \\
\hline \multicolumn{3}{|l|}{ Onset of first period } \\
\hline Earlier (at age 11 or earlier) & 111 & 16.9 \\
\hline Normative (at age $12-13$ ) & 433 & 66.1 \\
\hline Later (at age 14 or after) & 111 & 16.9 \\
\hline \multicolumn{3}{|l|}{ Sexually active } \\
\hline Yes & 299 & 45.6 \\
\hline No & 356 & 54.4 \\
\hline \multicolumn{3}{|l|}{ Smoking } \\
\hline Yes & 181 & 27.6 \\
\hline No & 474 & 72.4 \\
\hline Age when started sexual activity $($ mean \pm SD) & \multicolumn{2}{|c|}{$15.37 \pm 1.11(\min .13 ; \max .18)$} \\
\hline Number of partners $($ mean \pm SD) & \multicolumn{2}{|c|}{$2.20 \pm 1.55$ (min. $1 ; \max .12)$} \\
\hline Age when started smoking $($ mean \pm SD) & \multicolumn{2}{|c|}{$14.14 \pm 1.33$ (min. 9; $\max .18)$} \\
\hline Number of cigarettes per day (mean \pm SD) & \multicolumn{2}{|c|}{$8.20 \pm 5.59$ (min. $1 ; \max .20)$} \\
\hline
\end{tabular}

SD: standard deviation

Table 4 Socio-demographic characteristics of the sample according to the timing of the period

\begin{tabular}{|c|c|c|c|c|}
\hline Variables & $\begin{array}{l}\text { Early (11 years } \\
\text { and before) } \\
\text { n }(\%)\end{array}$ & $\begin{array}{c}\text { Normative (12- } \\
13 \text { years) } \\
\text { n }(\%)\end{array}$ & $\begin{array}{l}\text { Late (14 years } \\
\text { and after) } \\
\text { n }(\%)\end{array}$ & P-value \\
\hline Living place & & & & 0.939 \\
\hline Rural & 37 (17.7) & 137 (65.6) & 35 (16.7) & \\
\hline Urban & $74(16.6)$ & $296(66.4)$ & $76(17.0)$ & \\
\hline Mother's education & & & & 0.971 \\
\hline Elementary & $11(17.2)$ & $44(68.8)$ & $9(14.1)$ & \\
\hline Secondary & $71(17.2)$ & $270(65.4)$ & $72(17.4)$ & \\
\hline Higher & $29(16.4)$ & $118(66.7)$ & $30(16.9)$ & \\
\hline Father's education & & & & 0.112 \\
\hline Elementary & $14(25.5)$ & $32(58.2)$ & $9(16.4)$ & \\
\hline Secondary & $67(15.4)$ & $287(65.8)$ & $82(18.8)$ & \\
\hline Higher & $27(17.5)$ & $109(70.8)$ & $18(11.7)$ & \\
\hline Financial status & & & & 0.819 \\
\hline Poor & $8(21.6)$ & $21(56.8)$ & $8(21.6)$ & \\
\hline Average & $56(16.8)$ & $222(66.5)$ & $56(16.8)$ & \\
\hline Good & $47(16.5)$ & $190(66.9)$ & $47(16.5)$ & \\
\hline
\end{tabular}

${ }^{a} \mathrm{P}$-values were derived from chi-square test 
Regarding risk behaviors (sexual activity and tobacco use), Table 5 shows that both the age when starting sexual life and smoking began significantly earlier in case of girls who had their first period earlier.

Table 5 Risk behaviors (sexual activity and smoking habits) according to onset of their first period

\begin{tabular}{|c|c|c|c|c|}
\hline \multirow[t]{3}{*}{ Variables } & \multicolumn{3}{|c|}{ Onset of first period } & \multirow[t]{3}{*}{ P-value } \\
\hline & Earlier & Normative & Later & \\
\hline & n (\%) & n $(\%)$ & n (\%) & \\
\hline Sexually active & & & & $0.026^{\mathrm{a}}$ \\
\hline Yes & $52(46.8)$ & $184(42.5)$ & $63(56.7)$ & \\
\hline No & $59(53.2)$ & $249(57.5)$ & $48(43.3)$ & \\
\hline Smoking & & & & $0.192^{1}$ \\
\hline Yes & $36(32.4)$ & $121(27.9)$ & $24(21.6)$ & \\
\hline No & $75(67.6)$ & $312(72.1)$ & $87(78.4)$ & \\
\hline & Mean \pm SD & Mean \pm SD & Mean \pm SD & \\
\hline $\begin{array}{lr}\text { Age (years) } & \text { when } \\
\text { started } & \text { sexual } \\
\text { activity } & \end{array}$ & $14.90 \pm 1.12$ & $15.30 \pm 1.11$ & $15.95 \pm 0.85$ & $<0.001^{2}$ \\
\hline $\begin{array}{l}\text { Number } \quad \text { of } \\
\text { partners }\end{array}$ & $2.17 \pm 1.19$ & $2.21 \pm 1.73$ & $2.17 \pm 1.23$ & $0.976^{2}$ \\
\hline $\begin{array}{l}\text { Age (years) when } \\
\text { started smoking }\end{array}$ & $13.88 \pm 1.28$ & $14.04 \pm 1.26$ & $15.08 \pm 1.44$ & $0.001^{2}$ \\
\hline $\begin{array}{l}\text { Number of } \\
\text { cigarettes per day }\end{array}$ & $5.52 \pm 4.11$ & $9.13 \pm 5.75$ & $7.58 \pm 5.45$ & $0.002^{2}$ \\
\hline
\end{tabular}

${ }^{1} \mathrm{P}$-values were derived from chi-square test.

${ }^{2} \mathrm{P}$-values were derived from ANOVA.

Comparing the appearance of risk behaviors - sexual activity and smoking - by sociodemographic parameters, several differences can be seen in Table 6. With regard to sexuality, there was no significant difference regarding their living place. Adolescent girls whose mother's highest qualification was 8 years of schooling or less and father's qualification was 8 to 12 years of schooling, and who lived in lower family affluence claimed a significantly higher rate of sexual activity. With regard to smoking, all the analyzed parameters, except living place, 
showed significant differences: higher rate of tobacco use was reported by girls whose parents' highest qualification was 8 years of schooling or less, and with lower family affluence.

Table 6 Differences in risk behavior (sexual activity and smoking) according to sociodemographic parameters

\begin{tabular}{|c|c|c|c|c|c|c|}
\hline \multirow[t]{2}{*}{ Variables } & \multicolumn{2}{|c|}{$\begin{array}{c}\text { Sexual activity } \\
\text { n }(\%)\end{array}$} & \multirow[t]{2}{*}{$\begin{array}{c}\text { P- } \\
\text { value }^{1}\end{array}$} & \multicolumn{2}{|c|}{$\begin{array}{c}\text { Smoking } \\
\text { n }(\%)\end{array}$} & \multirow[t]{2}{*}{$\begin{array}{c}\text { P- } \\
\text { value }^{1}\end{array}$} \\
\hline & Yes & No & & Yes & No & \\
\hline Living place & & & 0.920 & & & 0.426 \\
\hline Rural & $96(45.9)$ & $113(54.1)$ & & $62(29.7)$ & $147(70.3)$ & \\
\hline Urban & $203(45.5)$ & $249(54.5)$ & & $119(26.7)$ & $332(73.3)$ & \\
\hline Mother's education & & & 0.041 & & & 0.005 \\
\hline Elementary & $33(50.8)$ & $32(49.2)$ & & $23(35.4)$ & $42(64.6)$ & \\
\hline Secondary & $198(47.6)$ & $218(52.4)$ & & $124(29.8)$ & $292(70.2)$ & \\
\hline Higher & $67(37.2)$ & $113(62.8)$ & & $33(18.3)$ & $147(81.7)$ & \\
\hline Father's education & & & 0.003 & & & 0.009 \\
\hline Elementary & $24(43.6)$ & $31(56.4)$ & & $21(38.2)$ & $34(61.8)$ & \\
\hline Secondary & $218(49.4)$ & $223(50.6)$ & & $126(28.6)$ & $315(71.4)$ & \\
\hline Higher & $52(33.5)$ & $103(66.5)$ & & $29(18.7)$ & $126(81.3)$ & \\
\hline Financial status & & & 0.014 & & & 0.002 \\
\hline Poor & $21(56.8)$ & $16(43.2)$ & & $16(43.2)$ & $21(56.8)$ & \\
\hline Average & $166(49.1)$ & $172(50.9)$ & & $104(30.8)$ & $234(69.2)$ & \\
\hline Good & $112(39.0)$ & $175(61.0)$ & & $61(21.3)$ & $226(78.7)$ & \\
\hline
\end{tabular}

${ }^{1} \mathrm{P}$-values were derived from chi-square test.

Sexual activity was analyzed to assess which factors had contributed to the odds of being sexually active (Table 7). The most influential proven factors were age, financial status, and regular smoking. As age increased by 1 year, the odds of having sexual intercourse increased by more than four units (OR: 4.42, CI: 3.45-5.67, $\mathrm{P}<0.001)$, and regular smoking increased (OR: 7.07, CI: 4.24-11.80, P<0.001), while poor financial status decreased (OR: 0.35, CI: 0.13$0.97, \mathrm{P}=0.043$ ) the odds of being sexually active.

Smoking was analyzed to assess the factors that are increasing the odds of being a regular tobacco user (Table 7). The most influential proven factors were menarche and sexual activity. Adolescent girls who had earlier (OR: 2.28, CI: 1.14-4.55, P=0.020) and normative (OR: 2.06, CI: 1.17-3.63, $\mathrm{P}=0.013$ ) onset of the first period were about twice as likely to smoke 
as girls with later onset of the first period. Being sexually active meant more than 7-fold odds of being a regular tobacco user (OR: 7.24, CI: 4.39-11.94, P<0.001).

Table 7 The odds ratios of smoking behavior and sexual activity according to sociodemographic characteristics (multivariable logistic regression models)

\begin{tabular}{|c|c|c|c|c|c|c|}
\hline \multirow[t]{2}{*}{ Variables } & \multicolumn{3}{|c|}{ Sexual activity } & \multicolumn{3}{|c|}{ Smoking } \\
\hline & OR & $95 \% \mathrm{CI}$ & P-value & OR & 95\% CI & P-value \\
\hline Age (years) & 4.42 & $3.45-5.67$ & $<0.001$ & 1.10 & $0.90-1.35$ & 0.364 \\
\hline \multicolumn{7}{|l|}{ Living place } \\
\hline Rural & 0.99 & $0.62-1.59$ & 0.988 & 0.99 & $0.65-1.53$ & 0.992 \\
\hline Urban & Ref. & & & Ref. & & \\
\hline \multicolumn{7}{|c|}{ Mother's education } \\
\hline Elementary & 0.99 & $0.44-2.25$ & 0.978 & 1.55 & $0.71-3.38$ & 0.271 \\
\hline Secondary & 0.87 & $0.49-1.54$ & 0.622 & 1.47 & $0.86-2.50$ & 0.157 \\
\hline Higher & Ref. & & & Ref. & & \\
\hline \multicolumn{7}{|c|}{ Father's education } \\
\hline Elementary & 1.17 & $0.46-2.93$ & 0.744 & 1.87 & $0.80-4.37$ & 0.147 \\
\hline Secondary & 1.75 & $0.96-3.20$ & 0.068 & 1.06 & $0.60-1.86$ & 0.850 \\
\hline Higher & Ref. & & & Ref. & & \\
\hline \multicolumn{7}{|c|}{ Financial status } \\
\hline Poor & 0.35 & $0.13-0.97$ & 0.043 & 1.77 & $0.76-4.13$ & 0.187 \\
\hline Average & 0.71 & $0.45-1.13$ & 0.145 & 1.25 & $0.82-1.91$ & 0.294 \\
\hline Good & Ref. & & & Ref. & & \\
\hline \multicolumn{7}{|l|}{ Menarche } \\
\hline Earlier & Ref. & & & 2.28 & $1.14-4.55$ & 0.020 \\
\hline Normative & 1.18 & $0.57-2.48$ & 0.654 & 2.06 & $1.17-3.63$ & 0.013 \\
\hline Later & 1.11 & $0.62-2.01$ & 0.725 & Ref. & & \\
\hline \multicolumn{7}{|c|}{ Sexually active } \\
\hline Yes & - & - & - & 7.24 & $4.39-11.94$ & $<0.001$ \\
\hline No & & & & Ref. & & \\
\hline \multicolumn{7}{|l|}{ Smoking } \\
\hline Yes & 7.07 & $4.24-11.80$ & $<0.001$ & - & - & - \\
\hline No & Ref. & & & & & \\
\hline
\end{tabular}

OR=Odds Ratio; $\mathrm{CI}=$ Confidence Interval; Ref.=reference category, $\mathrm{OR}=1.00$ 


\subsection{Visiting gynecologist and sexual knowledge}

Participants consisted of 14-18-year-old girls attending secondary grammar school or secondary technical school $(\mathrm{N}=589)$. Most participants of the survey estimated their financial background to be average or good (Table 8).

Table 8 Distribution of the sample according to sociodemographic characteristics $(\mathrm{N}=589)$

\begin{tabular}{lcc}
\hline Characteristics & n & \% \\
\hline Age (year) & 51 & 8.7 \\
\hline 14 & 202 & 34.3 \\
\hline 15 & 168 & 28.5 \\
\hline 16 & 108 & 18.3 \\
\hline 17 & 60 & 10.2 \\
\hline 18 & & \\
\hline Type of school attended & 333 & 56.5 \\
\hline Secondary grammar school & 256 & 43.5 \\
\hline Secondary technical school & & \\
\hline Financial situation & 2 & 0.3 \\
\hline Very poor (grade 1) & 35 & 5.9 \\
\hline Poor (grade 2) & 311 & 52.8 \\
\hline Average (grade 3) & 216 & 36.7 \\
\hline Good (grade 4) & 25 & 4.2 \\
\hline Very good (grade 5) & & \\
\hline
\end{tabular}

Half of the girls had already had a sexual contact. Most of the sexually active girls $(77.7 \% ; 39.0 \%$ of the total sample) had their first contact at the age of 15 or over and none of them had it before the age of 13 years. The average age at first intercourse was $15.37 \pm 1.12$ years. In total, $38.7 \%$ of them had already visited a gynecologist; more than half of these girls did so because of some kind of complaint (menstrual disorder, or discharge, etc.), and 18.1\% of them sought medical advice for contraception or screening (Table 9). 
Table 9 Distribution of sample according to preventive and sexual behaviour variables $(\mathrm{N}=589)$

\begin{tabular}{|c|c|c|}
\hline Characteristics & $\mathbf{n}$ & $\%$ \\
\hline \multicolumn{3}{|l|}{ Ever had sexual intercourse } \\
\hline Yes & 296 & 50.3 \\
\hline No & 293 & 49.7 \\
\hline \multicolumn{3}{|l|}{ Ever visited a gynecologist } \\
\hline Yes & 228 & 38.7 \\
\hline No & 361 & 61.3 \\
\hline \multicolumn{3}{|l|}{ Reasons for visiting gynecologist ${ }^{1}$} \\
\hline Contraception & 50 & 18.1 \\
\hline Menstrual disorder & 65 & 23.4 \\
\hline Vaginal discharge & 80 & 28.8 \\
\hline Cancer screening & 50 & 18.1 \\
\hline Other, consultation & 32 & 11.6 \\
\hline \multicolumn{3}{|l|}{$\begin{array}{l}\text { Knowledge about cervical screening (percentage of } \\
\text { correct answers) }\end{array}$} \\
\hline Screening is good for the prevention of cervical cancer & 433 & 73.5 \\
\hline The way of the test & 43 & 7.3 \\
\hline The test is painless & 338 & 57.4 \\
\hline Target population & 140 & 23.8 \\
\hline Frequency of screening & 465 & 78.9 \\
\hline The pathological result & 25 & 4.2 \\
\hline
\end{tabular}

${ }^{1}$ There were girls who consulted a doctor with several complaints, a total of 228 people consulted on 277 different complaints.

A comparison of characteristic features of the girls visiting and those not visiting a gynecologist is shown in Table 10. From the viewpoint of age, type of school and sexual life, there was a significant difference between the two groups. A higher proportion of girls aged $\geq 16$, girls attending technical school, smokers and those who had regular sexual contact had already visited a gynecologist; however, $41.2 \%$ of the sexually active girls had never consulted a gynecologist (Table 10). A significant difference $(\mathrm{P}<0.001)$ can be seen regarding the evaluation of financial background; those who had already visited a gynecologist estimated their financial background as worse (average 3.24 \pm 0.65 ) than those who had not visited one yet (average $3.47 \pm 0.68$ ). 
Table 10 Bivariate analysis of characteristics related to whether an adolescent girl received gynecology care or not

\begin{tabular}{|c|c|c|c|c|}
\hline Characteristics & $\mathbf{n}$ & $\begin{array}{c}\text { Ever visited a } \\
\text { gynecologist } \\
\text { n }(\%)\end{array}$ & $\begin{array}{c}\text { Never visited a } \\
\text { gynecologist } \\
\text { n (\%) }\end{array}$ & P-value ${ }^{1}$ \\
\hline Age (year) & & & & $<0.001$ \\
\hline 14 & 51 & $8(15.7)$ & $43(84.3)$ & \\
\hline 15 & 202 & $38(18.8)$ & $164(81.2)$ & \\
\hline 16 & 168 & $73(43.5)$ & $95(56.5)$ & \\
\hline 17 & 108 & $60(55.6)$ & $48(44.4)$ & \\
\hline 18 & 60 & $49(81.7)$ & $11(18.3)$ & \\
\hline Type of school attended & & & & $<0.001$ \\
\hline Secondary grammar school & 333 & $104(31.2)$ & $229(68.8)$ & \\
\hline Secondary technical school & 256 & $124(48.4)$ & $132(51.6)$ & \\
\hline Ever had sexual intercourse & & & & $<0.001$ \\
\hline Yes & 296 & $174(58.8)$ & $122(41.2)$ & \\
\hline No & 293 & $54(18.4)$ & $239(81.6)$ & \\
\hline \multicolumn{5}{|c|}{ Knowledge about cervical screening } \\
\hline $\begin{array}{l}\text { Screening is good for the } \\
\text { prevention of cervical cancer }\end{array}$ & & & & 0.906 \\
\hline Correct answer & 433 & $167(38.6)$ & $266(61.4)$ & \\
\hline Incorrect answer/DNT & 156 & $61(39.1)$ & $95(60.9)$ & \\
\hline The way of the test & & & & $<0.001$ \\
\hline Correct answer & 43 & $28(65.1)$ & $15(34.9)$ & \\
\hline Incorrect answer/DNT & 546 & $200(36.6)$ & $346(63.4)$ & \\
\hline The test is painless & & & & 0.001 \\
\hline Correct answer & 338 & $150(44.4)$ & $188(55.6)$ & \\
\hline Incorrect answer/ DNT & 251 & $78(31.1)$ & $173(68.9)$ & \\
\hline Target population & & & & $<0.001$ \\
\hline Correct answer & 140 & $75(53.6)$ & $65(46.8)$ & \\
\hline Incorrect answer/DNT & 449 & $153(34.1)$ & $296(65.9)$ & \\
\hline Frequency of screening & & & & $<0.001$ \\
\hline Correct answer & 465 & $199(42.8)$ & $266(57.2)$ & \\
\hline Incorrect answer/DNT & 124 & $29(23.4)$ & $95(76.6)$ & \\
\hline The pathological result & & & & 0.026 \\
\hline Correct answer & 25 & $15(60.0)$ & $10(40.0)$ & \\
\hline Incorrect answer/DNT & 564 & $213(37.8)$ & $351(62.2)$ & \\
\hline
\end{tabular}

${ }^{1}$ Results of chi-square test; DNT=doesn't know 
The multivariable logistic regression analysis showed that the chance of having visited a gynecologist was three times (OR: 3.21; 95\%CI: 2.05-5.02; $\mathrm{P}<0.001)$ as high in girls having sexual contact as those having no sexual contact (Table 11). The chance of visiting a gynecologist was increased (OR: 1.70; 95\%CI: 1.38-2.09; $\mathrm{P}<0.001)$ by each year of age. Financial background showed a lower chance of having visited a gynecologist among girls with a good financial background (OR: 0.72; 95\%CI: 0.54-0.97; $\mathrm{P}=0.033)$. The type of school did not show significant correlation with the chance of visiting a gynecologist (OR: $0.72 ; 95 \% \mathrm{CI}$ : 0.49-1.06; $\mathrm{P}=0.097)$.

Table 11 Multivariable logistic regression model for factors related to whether an adolescent girl received gynecology care or not

\begin{tabular}{lccc}
\hline Variables & OR & 95\% CI & P-value \\
\hline Age (year) & 1.70 & $1.38-2.09$ & $<0.001$ \\
\hline Type of school attended & & & \\
\hline$\quad$ Secondary grammar school & 0.72 & $0.49-1.06$ & 0.097 \\
\hline$\quad$ Secondary technical school & 1.00 & & \\
\hline Financial background (scale) & 0.72 & $0.54-0.97$ & 0.033 \\
\hline Ever had sexual intercourse & & & \\
\hline$\quad$ Yes & 3.21 & $2.06-5.02$ & $<0.001$ \\
\hline No & 1.00 & & \\
\hline
\end{tabular}

OR: odds ratio, CI: confidence interval.

In connection with cervical cancer screening, the widest known factor was its role in prevention and the suggested rate of screening (Table 9). A low proportion of participants $(7.3 \%)$ could give a correct account of what the screening really meant, and only $4.2 \%$ knew how to assess the obtained result, that is, what was considered pathological.

There was also a significant difference between girls visiting and not visiting a gynecologist in connection with the information on screening, with the exception of the importance of screening in prevention: those who had visited a gynecologist possessed more information (Table 10).

The average of score values on information about cervical cancer screening was $2.45 \pm 1.15$ (min: 0, max: 6), among those having visited a gynecologist $2.78 \pm 1.16$, and among 
those who had not visited a gynecologist $2.24 \pm 1.10$, and the difference was significant $(\mathrm{p}<0.001)$.

The distribution of individual score values is shown in Figure 2. The proportion of girls with comprehensive knowledge was quite low (0.7\%), and $4.4 \%$ of them had no knowledge about the screening at all. Those who had already visited a gynecologist knew significantly more about the screening; however, only $18.1 \%$ of them visited a gynecologist for specifically this purpose.

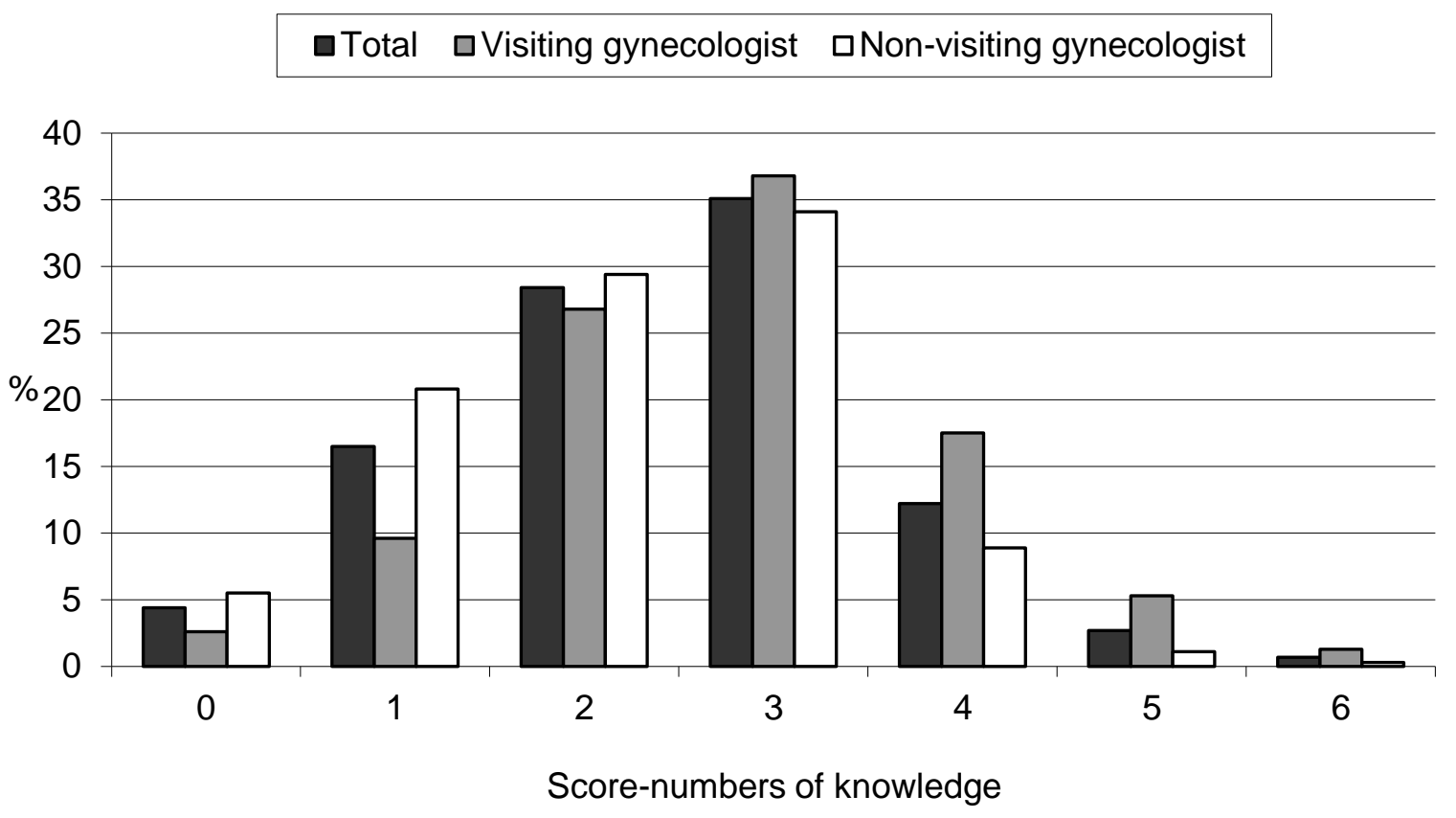

Figure 2 Distribution of the sample visiting or not visiting a gynecologist according to the scores for knowledge of cervical screening (result of chi-square test: $\mathrm{p}<0.001$ ).

Parents $(63.3 \%)$, especially mothers, were the main source of information related to sexual life; this was followed by the district nurse (49.2\%), friends $(32.3 \%)$, teachers $(27.7 \%)$, books and the media (27.5\%), physicians (21.6\%) and the Internet (16.5\%). There was a significant difference between those visiting and not visiting the gynecologist: those who visited the gynecologist identified the parent, the district nurse and the physician in a higher proportion as the source of information. According to the correlation analyses, the closest relation concerning screening was found when the physician was the source of information (Pearson correlation coefficient: $0.128 ; \mathrm{P}=0.002$ ), while in the case of parents, the correlation was lower 
(Pearson correlation coefficient: $0.099 ; \mathrm{P}=0.016$ ), and in case of the other sources, no correlation could be detected.

\subsection{Sexual education and knowledge}

For the question if they ever received sexual education, almost all sexually active girls answered yes, while this proportion was a little bit lower among the sexually inactive girls $(98.0 \%$ vs. $94.2 \%)$. The main source of knowledge about sexuality was the parent, followed by the health visitor, friends and teachers; however only every 5 th girl received information from a physician.

The girls' knowledge related to sexual life and prevention in accordance with sexual activity is shown in Table 12.

$70 \%$ of girls have already heard about emergency contraception; this proportion was above $90 \%$ among those who are sexually active (Table 12). The knowledge related to emergency contraceptive pill use (for how long is it worth to take) was insufficient in both groups. $96.3 \%$ of girls had information about the fact that protection is necessary already at the first sexual intercourse. In relation to the question about contraception we observed that sexually active girls are more informed than those who are sexually inactive, however, there are still insufficiencies among them (e.g. when to take the emergency contraceptive pill).

It should be highlighted that for the questions regarding the transmission of HPV only one participant gave completely correct answers; mostly (in $84.0 \%$ ) the answers were partly correct. Knowledge of HPV transmission was independent from sexual activity; possible transmission by kissing, petting or skin-to-skin contact of the genitals was known by $2.4 \%$, $2.2 \%$ and $16.6 \%$ of the participants, respectively. Merely every 3rd participant knew that the use of condom can not completely prevent the transmission of HPV, and moreover, knowledge was significantly worse among sexually active girls. Knowledge was also incomplete regarding the relationship between HPV and abnormal cervical cancer screening and abnormal cytological test result. It has to be emphasised that sexually active girls were again less informed regarding the previous two questions. 
Table 12 Knowledge of sexual life and prevention among sexually active and sexually inactive girls

\begin{tabular}{|c|c|c|c|c|}
\hline Knowledge & $\begin{array}{l}\text { Sexually } \\
\text { active } \\
\text { n }(\%)^{2}\end{array}$ & $\begin{array}{l}\text { Sexually } \\
\text { inactive } \\
\text { n }(\%)^{2}\end{array}$ & $\mathrm{n}(\%)^{2}$ & P value ${ }^{1}$ \\
\hline Knows emergency contraception & $284(93.1)$ & $316(57.4)$ & $600(70.1)$ & $<0.001$ \\
\hline $\begin{array}{l}\text { Exactly knows that for how long after } \\
\text { an unprotected sexual intercourse is it } \\
\text { worth to take the emergency } \\
\text { contraceptive pill }\end{array}$ & $174(57.0)$ & $137(32.5)$ & $311(42.8)$ & $<0.001$ \\
\hline $\begin{array}{l}\text { Knows that protection is also necessary } \\
\text { during the first sexual intercourse }\end{array}$ & $298(97.7)$ & $410(95.3)$ & $708(96.3)$ & 0.004 \\
\hline $\begin{array}{l}\text { Completely or partly knows the way of } \\
\text { HPV transmission }\end{array}$ & $245(81.4)$ & $445(85.6)$ & $690(84.0)$ & 0.220 \\
\hline $\begin{array}{l}\text { Knows that use of condom can not } \\
\text { completely prevent the transmission of } \\
\text { HPV }\end{array}$ & $76(25.0)$ & $188(36.4)$ & $264(32.2)$ & 0.001 \\
\hline $\begin{array}{l}\text { Knows that HPV infection can cause } \\
\text { abnormal cervical cancer screening } \\
\text { result }\end{array}$ & $63(20.9)$ & $130(25.5)$ & $193(23.8)$ & 0.002 \\
\hline $\begin{array}{l}\text { Knows that which cytological test } \\
\text { result means abnormality }\end{array}$ & $20(6.6)$ & $55(11.8)$ & $75(9.8)$ & 0.031 \\
\hline
\end{tabular}

${ }^{1}$ Result of the chi-square test

${ }^{2}$ Number/percentage of girls in the given category who has the knowledge. Percentages are given according to the proportion of valid answers (number of valid answers per question are also shown).

HPV: human papillomavirus 


\section{Discussion}

The results of our study, which was performed among adolescent girls, are consistent with the Hungarian data (Költő, 2016). Pénzes et al. (2017) have observed the duplication of cigarette smoking year by year in a cohort study among school aged children, which result is in accordance with our results (prevalence of smoking was $4.7 \%$ at the age of 13 , while it was $17.4 \%$ among the 15-year-olds). Similarly to the HBSC study (Költö, 2016), we observed a significant proportion of girls who have had their first sexual act before the age of 14 . However, at the same time their sexual knowledge (regarding transmission of HPV, contraceptive methods, etc.) was incomplete and there was a significant proportion of those who already have had sex but have never had a gynecological examination. Our results highlighted the educational deficiencies of sexual - and in a broader sense reproductive - life.

\subsection{Menarche as a predictor of risk-taking behaviour}

Most of the girls had their first period at the age of $12-13$. The bivariate analyses showed that risk behaviors occurred at a higher rate in those whose parents' education was at a lower level and who have had lower family affluence. Participants who have had earlier onset of their period also have had smoked and have had sexual contact at an earlier age than girls with later onset of their period. According to the multivariate analyses of the factors that have been contributing to the occurrence of risk behaviors, the most influencing parameters were the age at menarche and active sexuality in case of smoking, while the age of girls, smoking, and financial background were the most influencing parameters in case of sexual activity.

The beginning of puberty is a complex hormonal process. In girls, menarche is one part of this maturation. The mean age at menarche in the recent study population was consistent with the Hungarian population data and also similar to US data (Bodzsár \& Zsákai, 2002; Chumlea, et al., 2003).

The results of a systematic review highlighted that early menarche was associated with early marriage, early sexual initiation, early pregnancy and childbirth, and some STIs in lowerincome regions of the world; similar to what has been observed in high-income countries (Ibitoye, et al., 2017). Another review published by Azevedo et al. (2017) described that early 
maturation was associated significantly with the use of alcohol, cigarettes and illegal drugs, early sexual initiation, sedentary behaviors and involvement in fights.

According to the bivariate analyses of our study, girls who had their first period earlier (at age 11 or before) were at an increased risk of starting smoking and even having sexual intercourse. This reflects the outcomes of the above-mentioned investigations. Kaltiala-Heino et al. (2011) found that the early onset of puberty in girls was associated with substance use at age 15 .

Belsky et al. (2010) showed that younger age at menarche predicts higher sexual risktaking. In research by Boden et al. (2011) it has been highlighted that females reaching menarche at an earlier age are at an increased risk of early pregnancy and STIs by age 18 . Gaudineau et al. (2010) found relationships between early menarche and early sexual initiation in France. Also, Glynn et al. (2010) stated that women with early menarche start sex early.

Regular smoking and sexual activity was seen in girls with poorer socio-economic status. This relationship was identified by Downing and Bellis (2009) in an indirect relation as earlier pubertal onset was associated with poorer parental socio-economic status and earlier puberty predicted alcohol consumption and/or smoking in the UK.

The multivariable logistic regression models analyzed some factors contributing to risk behaviors, such as socio-demographic characteristics (age, living place, parents' education and financial status), onset of first period (menarche), and presence of other risk factors. With regard to the effect of menarche, some differences can be seen: girls with earlier menarche were at an increased risk of being regular tobacco users (Downing \& Bellis, 2009; Kaltiala-Heino, et al., 2011; Jean, et al., 2011; Rada, 2014).

According to tobacco use, our findings are consistent with the findings of Jean et al. (2011) who stated that girls who matured early had a 2.5-fold increased risk of experimenting with cigarettes compared with those who had an average-to-late age at menarche.

The earlier onset of sexual life seems to be an increasing problem in Central and Eastern European countries. In Serbia, in 2008, 44.2\% of adolescents between 15 and 19 years had sexual intercourse (girls $36.5 \%$, boys $55.6 \%$ ); the first sexual intercourse of adolescents was at the mean age of 16.1 years (boys: 15.8 years; girls: 16.38 years) (Kapamadzija, et al., 2010).

Diaz-Franco et al. (2013) showed that 1 year after the menarche, adolescent girls had a boyfriend, and 2 years after the menarche, they had their first intercourse. 
In our study, only the bivariate analysis showed a significant correlation between earlier menarche and sexual activity, but after controlling for other variables (especially for age), the association disappeared.

\subsection{Visiting gynecologist and sexual knowledge}

In our study, only half of the sexually active girls had already visited a gynecologist; most of them did so because of some kind of complaint. The multivariable analyses showed correlations between age, financial background, sexual life, and the chance of visiting a gynecologist. Older girls with unfavorable financial background had a higher chance of having visited a gynecologist, although the most important factor for teenage girls in visiting a gynecologist was whether they were sexually active or not, which can be assessed as favorable; however, the bivariate analysis proves that a significant proportion of girls having sexual contact had never consulted a gynecologist. It is doubtful to what extent these youths are prepared for responsible sexual life. The consequences of premature sexual contact, especially an unwanted pregnancy, can ruin the life of the youth, whether they decide to keep, or terminate the pregnancy.

Knowledge about cervical screening and the factors influencing it have been analyzed in several studies. Nwankwo et al. (2011) found very poor knowledge and practice of cervical cancer screening among Nigerian women, and they concluded that effective female education and free mass screening are necessary for any successful cervical screening program in Nigeria.

A study in Malaysia found that age, marital status, ethnicity, monthly family income and faculty are significantly associated with knowledge of cervical cancer screening among young women (Al-Naggar, et al., 2010).

Maxwell et al. (2001) described the relation between age and knowledge about cervical cancer screening among Canadian women.

Among Australian women, the knowledge of cervical cancer and screening is good, and better knowledge has been found among sexually active women (Shand, et al., 2010).

Our study showed that the overall knowledge about cervical cancer screening was quite low, but higher knowledge was found among those who had visited a gynecologist. Among those girls who had already visited a gynecologist, there was a strong correlation between knowledge and the physician as the source of information. 
In our study, more than $40 \%$ of the subjects reported that cervical screening had been painful. The misconception about the test being painful was marked as a barrier to participation by several other studies (Al-Naggar, et al., 2010; Maaita \& Brakat, 2002).

Twenty-seven percent of young Hispanic women who had had a Pap smear test and $48 \%$ of those who had never had a Pap smear believed that the test was painful (Byrd, et al., 2004).

Focus group discussions in Peru revealed that most women did not know the purpose of Pap smears; fear, embarrassment, and lack of knowledge were the main barriers identified for not getting Pap smears (Paz-Soldán, et al., 2010).

The most common barriers to obtaining a Pap test reported by sexually active adolescent girls in West Virginia were embarrassment (64\%), pain/discomfort (57\%), fear of cancer (27\%), and fear of parents discovering their sexual activity (25\%). Based on the information obtained in this study, the authors recommended changes in school health programs that target adolescent girls (Jubelirer, et al., 1996).

It has been proved that the base of healthy adult life can be traced back to early childhood (Ben-Shlomo \& Kuh, 2002).

From the viewpoint of the evolution of a health-conscious attitude, refraining from smoking, alcohol, and drugs, and having a safe sexual life, adolescence is an especially critical period. Early sexual life without appropriate information or the high prevalence of smoking among the youth proves that there are grave short comings in the field of health awareness among the youth of today. Traditions concerning visiting a doctor - a gynecologist - can also be characterized as unfavorable. Hungarian women usually consult a gynecologist when they experience a complaint, pain, and not with an eye on screening; the rate of the attendance at the 3 -year cervical screening hardly reaches $50 \%$ in the adult female population between 2003 and 2005 (Boncz, et al., 2007).

If participation is low among adults, it can be predicted that their female offspring will not consult experts more frequently, either. Most youngsters surveyed in our study consulted a doctor only due to having some kind of complaint. However, it would be highly recommended for the young to visit a gynecologist who specialized in pediatric and adolescent gynecology before starting their sexual life, and this specialist would provide them with information concerning contraception, prevention of sexually transmitted diseases and screening.

Our study revealed a correlation between knowledge about cervical screening and visiting the gynecologist in teenage girls. In the published work, we did not find further studies 
about the direct relation between cervical screening knowledge and consulting a gynecologist, but several studies have described the limits of teachers (Wight, et al., 2002) or school nurses (McFadyen, 2004) delivering sexual education, and have emphasized the importance of the physician, especially the gynecologist, in the comprehensive sexual education of young people (Delisi \& Gold, 2008; Huff, et al., 2009; Nelms, 2003; Shafii \& Burstein, 2009; Sieving, et al., 2002).

Regarding the various forms of education, the RIPPLE study found no significant difference between the effects of peer-led or teacher-led sexual education programs among teenagers (Stephenson, et al., 2004).

Italian researchers have stated a need for collaboration between schools and local health services to promote knowledge and prevention in reproductive health among teenagers (Donati, et al., 2000).

The implementation of a sexual education curriculum within the Department of Obstetrics and Gynecology of an academic medical centre showed an increase in knowledge, and a shift in attitude toward delaying adolescent sexual debut (Sulak, et al., 2006).

Although the importance of the first teenage consultation with the gynecologist and its essential elements are described by several guidelines (Sieving, et al., 2002; Delisi \& Gold, 2008; Huff, et al., 2009; Shafii \& Burstein, 2009), there is no uniform education concerning the preparation for sexual life in Hungary. Apart from the information obtained from medical experts, it is important that all young girls/women should master certain basic knowledge on sexual maturation, contraception, the essence of the gynecological examination and its necessity. In most cases, it is the teacher's decision whether to dedicate a lesson to this topic or to seek the help of an expert. Our model test aimed at complementing this type of school education with an additional lecture held by a gynecologist. In order to make our lecture really necessity-oriented, before the education, we surveyed the students' knowledge concerning contraception, sexually transmitted diseases, and screening, and the final content of the lecture was adjusted to the shortcomings that had come to light. The target group of the program had originally been secondary school students, but taking into consideration that a great number of youth start their sexual life at the age of 14 , were realized that education should be started at the ages of 13-14 years. Our experience may contribute to the compilation of an educational content concerning sexual education, which all 13-14-year-old adolescents should become acquainted with, not just the girls. 


\subsection{Improving sexual education}

Besides the results of the present study, unfavourable statistical data of the Hungarian population regarding the number of live births and induced abortions, cervical cancer mortality, participation rates of screenings, or vaccination rates of HPV (which is freely available in Hungary since 2014) also underline the timeliness of our objective - the improvement of interdisciplinarity and extension of sexual education. There is a need for repeated, ageappropriate sexual education to make it possible for young persons to start their sexual life with proper knowledge and to become health conscious adults, who use safe contraceptive methods and participate on screenings. For this aim, sexual counselling should be initiated in a young age, with special emphasis on the improvement of knowledge regarding contraception, gynecological cancer screening, sexually transmitted diseases and HPV vaccination. There is a significant proportion of young people who has their first sexual intercourse at the age of 14 or younger (Költö, 2016), therefore it would be crucial to start sexual education - with the involvement of life skill improving programs of a wider approach - during the first years of primary school, fitted to the level of development of the given age group. The misconception that educational programs in connection with sexuality would increase sexual activity has already been refuted for decades by Kirby and Coyle (1997) in a meta-analysis reviewing 35 health promotion programs in the field of sexuality. Furthermore, this was also supported by the dramatic decrease in adolescent fertility in the United States after 2011, when the government committed itself to school-based prevention and broke with the Abstinence-OnlyUntil-Marriage (type 1 sexual education) policy (Lindberg, et al., 2016; Society for Adolescent Health and Medicine [SAHM], 2017; Thaxton \& Espey, 2017).

Based on our observations and literature data it can be stated that adolescents by the age of 14 already have the basic knowledge about the parts and functions of genitals, hormonal and nervous system characteristics, but they are less informed about the natural way of conception, contraception and sexually transmitted diseases. Therefore, it would be necessary to deliver this knowledge from early childhood in an age-appropriate manner. The basis of the holistic approach is that sexual education starts at birth. In the first years the role of parents is elementary, but after admission to institutions, infants' nursery, kindergarten and school should also include further improvement of these skills in their tasks, in an organised and controlled framework, which is based on a scientific basis, age-appropriate and incorporated in the 
curriculum. In the WHO guideline "Standards for Sexuality Education in Europe" published in 2010 there is a detailed discussion of the appropriate level of knowledge according to age groups (WHO Regional Office for Europe and BZgA [WHO-BZgA], 2010).

Nowadays, the role of teenager pregnancies in obstetric events has changed; a high proportion of pregnancies ends with induced abortion (every 3rd pregnancies). The chance of a subsequent unwanted pregnancy is significantly higher among those teenagers, who already have had an obstetric event (abortion or delivery) (Sober, et al., 2017; KSH, 2018).

Today, on the one hand the earlier the biological maturation and first sexual intercourse, but on the other hand the later the age of having children are typical. The interval between the first sexual intercourse and having the first child is increasing. Since contraceptives are applied for longer periods of time, individualised contraception counselling would be crucial. During adolescence, any incorrectly chosen method of contraception is better than an unwanted pregnancy, but efforts should be taken to choose the most appropriate way of contraception for the adolescent.

The task of (pediatric) gynecologist is not exclusively the diagnosis and treatment of diseases, but prevention has to be a primary and most important aim, too (Borsos, 2016; Papp, 2017). From the viewpoint of health education, adolescent girls attending pediatric gynecology specialist's consultation constitute the most susceptible group. At the specialist's consultation effective steps can be taken against unwanted pregnancies under the age of 19 and against sexually transmitted diseases. The lack of contraception can be traced back to incomplete sexual education, improper use of condom, insufficient knowledge about and difficult access to emergency contraception, and furthermore to fear of parents, infertility and side effects, and last but not least to financial reasons.

It has to be mentioned that user dependent errors are significantly higher in this age group, therefore long term reversible contraceptive methods, which are independent from the user, can be safer compared to those where activity of the adolescent is also necessary (short term contraceptive methods) (Major, 2014; Major, 2016; ACOG, 2017a; ACOG, 2018).

The task of the obstetrician-gynecologist and pediatric gynecologist include sexual education of the adolescents, emphasising the necessity of contraception in order to decrease the number of unwanted pregnancies, and informing about the prevention of sexually transmitted diseases (ACOG, 2016; ACOG, 2017b). 
At the selection of contraceptive method, besides professional viewpoints (ACOG, 2017a), possibilities and needs of patients and their relationship with parents should also be considered. It is important to know the novelties and to give clear and detailed information about them to the adolescent, and if possible, talk to the adolescent privately (Kaunitz, 2018).

At selection, age, menstruation cycle and related complaints, chronic diseases, regularly taken medications, family history and especially the requirements of the adolescent and the parents should be considered (ACOG, 2017a). Patients' knowledge, requirements and fears should be checked according to the principle of Good Contraceptive Counselling Practice. It is recommended to inform the patient about the medical indications and contraindications, and to talk about all of the available methods. Information should be given about the advantages and disadvantages of the method, and refusal should also be accepted (Dehlendorf, et al., 2014). Decision (selection) should be done along medical reasons and individual priorities (ACOG, 2017b; Kaunitz, 2018).

Application of Long-Acting Reversible Contraceptive (LARC) methods, which are also applicable among young people, is spreading throughout the world. These methods involve DMPA (depomedroxyprogesterone acetate - with FDA black box warning), subdermal contraceptive implants (not available in Hungary), IUDs (intrauterine device) and LNG-IUS (levonorgestrel intrauterine system). While 20 years ago it was an accepted opinion that intrauterine devices were not recommended for women who have never borned a child, nowadays these devices are considered as first-choice methods for adolescents because of their safety and reliability. Several national and international committee opinion and guideline have a statement about LARC methods and recommend them as first-choice methods for the young people and for nulliparous women (ACOG, 2017a; ACOG, 2018; Committee on Adolescence [CA], 2014; Curtis, et al., 2016; Francis \& Gold, 2017).

It has been proven in the „Contraceptive CHOICE Project” that if any contraceptive method can be chosen for free, most women (70\%) will decide to apply a LARC method. Young people between the age of 18 and 20 preferred IUD, while the youngest age group (14-17 years of age) have chosen the implant (Mestad, et al., 2011). In a second study continuation rates of LARC and non-LARC methods were studied in a 2 years period; LARC method was continued in $77 \%$, while non-LARC method was continued in 41\% (O'neil-Callahan, et al., 2013). The study investigating the use of LNG-IUS among young people have shown similar results, i.e. $16.8 \%$ of the participant discontinued the use of the method within one year. This study has 
also confirmed the safety of the LNG-IUS method among adolescents (Diedrich, et al., 2017; Gemzell-Danielsson, et al., 2016). Forasmuch as the implant is not available in Hungary, DMPA is only used in exceptional cases. Among LARC methods, IUD and LNG-IUS can possibly be used in Hungary.

Our fears and doubts (pelvic inflammatory disease, menstrual disorders, unwanted pregnancy, infertility, etc.) can be dispelled by the Resolution of the Professional College of Obstetrics and Gynecology, Assisted Reproductive Section: Intrauterine contraception in nulliparous women (Major, 2014), and several other international studies as well. There are papers about the eligibility criteria for using the LARC method, the circumstances of IUD/ LNG-IUS insertion, about that routine prophylactic antibiotic treatment is not justified, but based on sexual history patients can be categorised and screening can be performed for sexually transmitted diseases (Arisi, et al., 2014; Caddy, et al., 2014; Diedrich, et al., 2017; GemzellDanielsson, et al., 2013; Pritt, et al., 2017; Sufrin, et al., 2012; WHO, 2015).

Special attention should be paid on those adolescents who underwent induced abortion or had live birth. They have to be informed about further ways of safe contraception during pregnancy and hospital stay (ACOG, 2017a; Francis \& Gold, 2017; Tomlin, et al., 2017).

A considerable problem in Hungary is that the pediatric gynecologist is only attended in case of an existing unwanted pregnancy, complaints and sexually transmitted diseases. Therefore, it would be necessary to assess adolescents appearing in any area of health care but primarily those attending the pediatrician from the viewpoint of sexual life (Breuner, et al., 2016).

It should be emphasised that most adolescents seeking for medical help experience sexuality related communication as a stressful situation, therefore it is of high importance that we should never judge them, do not express disapproval, but we should try to help and give information suitably in the given situation. We suggest the propagation of the preventive attitude, the consultation about sexuality and contraception in pediatrics (Breuner, et al., 2016; CA, 2014; Francis \& Gold, 2017; SAHM, et al., 2014), and timely referral of these adolescents for specialist care. The adolescent already knows her pediatrician and therefore can open more easily in confidential questions and is willing to share such information, which is not yet know by the parents either. By asking an innocent question (e.g. "Do you have a boyfriend?") we can raise the topic of contraception and sexually transmitted diseases. It is also important to have information about the sexual history of the adolescent. We should raise the attention of these 
young people to that by the initiation of sexual life two very important questions arise. One is the possibility of unwanted pregnancy; the other is the prevention of cervical cancer and sexually transmitted diseases.

Adolescents should also be informed that physical examination by a gynecologist or by a pediatric gynecologist will be necessary annually (Papp, 2017), during which the specialist will decide on the necessary examinations based on the health status of the patient. Attending the gynecologist and contraception counselling should not inevitably mean physical (bimanual) examination (overcome fears); for excluding pregnancy urinary test is also suitable (Raidoo \& Kaneshiro, 2017), however after a while, annual physical examination of sexually active adolescents will become essential (Papp, 2017).

According to the latest Hungarian guideline first cervical cancer screening (cytology samples) should be done 2 years after the initiation of sexual life, but not later then the age of 21. Further application of this indication is also included in the new Hungarian guideline which is based on international recommendations (Koiss, et al., 2017; Póka, 2018).

Adolescents should be encouraged to start a discussion with their parents about sexual life. It should be highlighted that the media can be a useful source of information, but there are certain undesirable websites (Breuner, et al., 2016).

Time and atmosphere should be appropriate for the consultation, information given should be complete and free of charge, and we should make the adolescent feel that her choice is taken into consideration maximally (SAHM, et al., 2014). They should be informed about condom use at any time, dual use (Raidoo \& Kaneshiro, 2017), emergency contraception, and non-contraceptive benefits of combined oral contraceptives.

The task and responsibility of those doing sexual education is significant: how they can perform sexual education in a way, which will not only show the dark side and will not discourage them from doctors and examinations. By reviewing the international literature, we can find existing guidelines on how to take the medical and sexual history, and how to perform a comprehensive psychosocial evaluation within 15 minutes (Brook, et al., 2014; Doukrou \& Segal, 2018).

Not only medical, but educational documents are also available about the basic principles of comprehensive sexuality education (CSE). Comprehensive or holistic sexuality education is characterised by a positive approach to sexuality that accepts sexual feelings, desire and pleasure as essential components of young people's sexuality (International Planned 
Parenthood Federation [IPPF], 2017 and WHO-BZgA, 2010 cited in Bonjour \& Vlugt, 2018). CSE addresses not only physical, emotional, social and cultural aspects, but it also includes aspects like friendship, feelings of safety, intimacy, gender, security, pleasure and attraction. CSE is not value free; it promotes values such as gender equality, dignity, respect for others, awareness of sexual and reproductive rights and freedom from discrimination, exclusion and sexual violence CSE (IPPF, 2017 and WHO-BZgA, 2010 cited by Bonjour \& Vlugt, 2018). The key international standards and documents describing the principles of CSE are:

- Standards for Sexuality Education in Europe (WHO-BZgA, 2010);

- International Technical Guidance on Sexuality Education (United Nations Educational, Scientific and Cultural Organization [UNESCO], 2018);

- DELIVER+ENABLE TOOLKIT: Scaling-up comprehensive sexuality education (CSE) (IPPF, 2017);

- Comprehensive Sexuality Education (Bonjour \& Vlugt, 2018).

In this context, sexuality education aims to support and protect children and young people in their sexual development, for them to benefit from global innovations while being critical towards untrue, misleading (online) information and capable of handling contradicting messages on sexuality and relationships (Bonjour \& Vlugt, 2018).

Ideas on the age at which sexuality education should start are also very different. Most of the countries start with sexuality education from 12-14 year of age or older, but in some Western European countries (e.g. Netherlands, Denmark), they start at a younger age (from 4 or 5 years of age) (Bonjour \& Vlugt, 2018).

Today, parents, other family members, and other informal sources are often insufficient from the point of sexuality education, because these informal sources themselves often lack the necessary knowledge, particularly when complex and technical information is needed (WHOBZgA, 2010).

Effective sexuality education takes place in a safe learning environment, where students and their educators feel comfortable to participate and their privacy is respected, where they are protected from harassment and where the school ethos reflects the principles of the CSE content (Pound et al., 2017 cited by Bonjour \& Vlugt, 2018). The schools are defined as the main settings of sexuality education, but the cooperation between the education sector and the health sector is essential. The „Whole School Approach” means the involvement of teachers and staff 
at schools, but also reaching out to parents, health workers and community leaders. Additionally, recent reviews (e.g. Chandra-Mouli, et al., 2015; Svanemyr, et al., 2015 cited by Bonjour \& Vlugt, 2018) strongly call for multicomponent, comprehensive approaches in addressing the social and structural conditions that underlie young people's SRHR (Sexual and Reproductive Health and Rights) problems.

Scientific evidence-based guidelines (ACOG, 2016; Breuner, et al., 2016; Brook, et al., 2014; Doukrou \& Segal, 2018; SAHM, et al., 2014) should be adopted and followed in the Hungarian primary (GPs, pediatricians) and specialized care (especially dermatologist, gynecologist and pediatric gynecologist), too. More time should be spent on a patient, and by questioning, we should help in formulating the aim of their visit. The assistance of the pediatricians is essential. Role of health visitors is also crucial in sexual education, since mostly they are the persons who have contact with the young people and who can establish a confidential relationship with them. Measurable result is only attainable with consequent application and timely initiation of sexual education; there is a need for repeated, ageappropriate sexual education.

The adaptation of the concept and content of international guidelines could contribute to develop the new approach of sexuality education - the CSE - in Hungary.

\subsection{Limitations of study}

In interpreting the results of the present study, it is important to keep in mind its limitations.

The first thing is the study design: it was a cross-sectional survey, which is not able to draw cause-and-effect relationships. So, we cannot determine exactly why girls with earlier age of menarche begin tobacco smoking earlier, which factors add to this, and in what proportion; we cannot exactly define to what extent the presence of information or the lack of it correlates with visiting a gynecologist or not. In other words, are those who consulted a doctor more informed or was their information provided by the doctor? It can only be revealed by a followup survey.

Second, because of the way the questions were asked, it did not turn out whether visiting a gynecologist took place before or after the start of sexual life; however, as the majority specified a certain complaint for the reason of consulting a doctor, we can conclude that in most cases the aim of visiting a doctor was not prevention. 
Third, completing the survey took place before the education, and there was no followup because the survey aimed at revealing the girls' existing knowledge; as a result, we possess no objective data about the increase of knowledge on the matters concerned.

The other limiting factor was the number of participants. Also, a self-selection bias can be mentioned, as the participants were not recruited systematically; the participation was voluntary, so the study population does not represent Hungarian school-aged girls.

Also, the questionnaire has its limitations, a survey bias. The Hungarian question about sexual life did not unequivocally refer to "ever having sex" or "having regular sex". The "yes" answers to this question were, therefore, evaluated as "ever having sex", which is true in either of the above-mentioned cases.

Possible influencing variables that can affect the results were not assessed, like social influences, beliefs, attitudes, cultural influences, the norms of the broader social environment (school, community), biological characteristics, personality traits, behavioral control, sociability, intelligence, accessibility, pricing of tobacco products, parental smoking, sibling smoking, family experiences (divorce, separation, interactions among family members), strong attachment to peers, religiousness, self-esteem, emotional distress, coping styles, etc. 


\section{Conclusions}

To start sexual life at a suitable time and with the appropriate contraception, it is of utmost importance to provide teenagers with the necessary information in time. There is always some debate about the sexual education planned for adolescents, about its method and content, and about the person who should provide it.

With the renewal of the Hungarian National Core Curriculum, these topics have been marginalized in the modules; there are no compulsorily implemented training programs. Another problem is the decreasing number of the real type of courses. In most cases, the education is too late, due to the different level of development of the children (failed students). It was a general opinion that by the age of 14 , these adolescents have had information about the structure and functioning of the genitalia, and about the hormonal and nervous systems. At the same time, they know only a little about the natural ways of conception, about contraception and about STIs.

Early sexual life increases the risk of HPV infection in young ages and risk of cervical cancer. It is also well known that nowadays young people have their first sexual act at a younger age, but without having proper knowledge about sexuality. Because of this reason, sexual counselling should be started in a young age, with special emphasis on the improvement of knowledge regarding contraception, gynecological cancer screening and HPV vaccination. It has to be stressed that after a natural HPV infection long term protection will not evolve against a subsequent infection; maximal protection against cervical cancer can only be attained by the participation on screening together with the application of HPV vaccine. It should also be highlighted that regular cervical cancer screening is still required after vaccination.

In the light of our findings, the reconsideration of health- and sexual education in Hungary is needed. Our findings could also be accepted in the reconsideration of prevention programs of school-aged children, taking into account that earlier menarche is in connection with risk-taking behavior. Implementation of these programs at an earlier age should be desirable to avoid consequences (i.e. STIs or early pregnancy) of the irresponsible/uninformed behavior of physically matured but mentally and emotionally immature adolescents.

Young people need varied, professional and continuous sexual education, and the most authentic opinion and advice in this field can be provided by the gynecologist. The participation of a gynecologist in conducting the information is of high importance because in our fast- 
changing world the advice provided by parents and friends is not always reliable. In Hungary, there are pediatric and adolescent gynecology out patient departments in several cities, where it is possible to obtain gynecological instruction before the sexual act. With repeated age-related and continuous education, it is possible in the long run to achieve our aim, so that the young should begin their sexual life being aware of its dangers and prepared for contraception, thus reducing the number of unwanted pregnancies among 14-18-year-old girls. Teenage experiences and the development of the gynecologist-patient relationship in this period exert a huge influence on adulthood habits of visiting a doctor, including participation in cancer screening.

The results of other studies also highlighted the need to improve and standardize sexuality education in several - mainly Central and Eastern European - countries. Comprehensive sexuality education was presented in several international documents of WHO, UNESCO, IPPF. These guidelines can play an important role in introducing or improving sexual education in our region.

Our results highlighted the educational deficiencies of reproductive life, which is a complex task to solve, to address the changing approach of national healthcare and education systems. It is essential to continue incorporating sexual education into education from early childhood to young adult age. A repeated, age-appropriate sexual education makes it possible for the young to start their sexual life with proper knowledge and to become health conscious adults, who are vaccinated and participate on screenings. Teachers, staff of schools and all health care workers who are in contact with adolescents during their work must be involved in sexual education. 


\section{Key messages}

- Our study results showed that a remarkable proportion of adolescent girls began to smoke and had sexual experience at an average age of 13-14 years; girls with earlier onset of menarche are more likely to have this experience at younger ages. The correlation of these analyzed behavioral risk factors can also be seen: girls who smoke have an increased risk of earlier sexual initiation and vice versa. Our finding that earlier menarche is in connection with risk-taking behaviour could be considered in connection with the prevention programs among school-aged children.

- The overall knowledge about cervical cancer screening was low in the study population, but the knowledge of those girls who had already visited gynecologist were better. The knowledge about HPV infection and its prevention was also limited. Young people need professional sexual education, and the most authentic opinion and advice in this field can be provided by the gynecologist.

- A repeated, age-appropriate sexual education is essential for the young to start their sexual life with proper knowledge and to become health conscious adults.

- Scientific evidence-based guidelines of comprehensive sexuality education should be adopted in Hungary. The adaptation of the international guidelines could contribute to develop the new approach of sexuality education in Hungary.

- The organization of comprehensive sexuality education is difficult. A national policy or national strategy supporting CSE is essential. Teachers, staff of schools and all health care workers who are in contact with adolescents during their work must be involved in sexual education. The under- and/or postgraduate training of teachers involving evidence-based knowledge about human sexual development and behaviour, methodological aspects of how to develop social skills, positive attitudes and values towards sexuality is necessary.

- We suggest the propagation of the preventive attitude, the consultation about sexuality and contraception in primary care by GPs and pediatricians. Role of health visitors is also crucial in sexual education, since mostly they are the persons who have contact with the young people. All of them has a chance to refer the adolescents to the specialists. The participation of a gynecologist in conducting the information is of high importance because in our fastchanging world the advice provided by parents and friends is not always reliable. 


\section{References}

A Kormány 110/2012. (VI. 4.) Korm. rendelete a Nemzeti alaptanterv kiadásáról, bevezetéséről és alkalmazásáról. (2012). Magyar Közlöny, 66, 10635-10847.

Al-Naggar, R. A., Low, W. Y. \& Isa, Z. (2010). Knowledge and barriers towards cervical cancer screening among young women in Malaysia. Asian Pacific Journal of Cancer Prevention, 11, 867-873.

American College of Obstetricians and Gynecologists. (2016). Comprehensive sexuality education. Committee Opinion No. 678. Obstetrics and Gynecology, 128, e227-230.

American College of Obstetricians and Gynecologists. (2017a). Adolescent pregnancy, contraception, and sexual activity. Committee Opinion No. 699. Obstetrics and Gynecology, 129, e142-149.

American College of Obstetricians and Gynecologists. (2017b). Counseling adolescents about contraception. Committee Opinion No. 710. Obstetrics and Gynecology, 130, e74-80.

American College of Obstetricians and Gynecologists. (2018). Adolescents and long-acting reversible contraception: implants and intrauterine devices. Committee Opinion No. 735. Obstetrics and Gynecology, 131, e130-139.

Arisi, E., Bruni, V., Di Spiezio Sardo, A., Dubini, V., Gubbini, G., \& Parazzini, F. (2014). Italian guidelines on the effective and appropriate use of intrauterine contraception. Italian Journal of Gynaecology and Obstetrics, 26(4), 7-20.

Arnold, P. (2016). Dohányzási szokások. In: Németh, Á., \& Költő, A. (eds.). Egészség és egészségmagatartás iskoláskorban 2014. Az Iskoláskorú gyermekek egészségmagatartása elnevezésü, az Egészségügyi Világszervezettel együttmüködésben megvalósuló nemzetközi kutatás 2014. évi felméréséről készült nemzeti jelentés. Nemzeti Egészségfejlesztési Intézet, Budapest, pp. 47-57.

Azevedo, K., dos Santos, I. K., da S. Dantas, P. M., Knackfuss, M. I., Bento, T., Carlos Leitão, J., \& de Medeiros, H. J. (2017). Pubertal maturation and health risk behaviors in adolescents: a systematic review. Epidemiology, Biostatistics and Public Health, 14(1), e12156-1- e12156-10.

Bano, F., Kolhe, S., Zamblera, D., Jolaoso, A., Folayan, O., Page, L., \& Norton, J. (2008). Cervical screening in under 25s: a high-risk young population. European Journal of Obstetrics \& Gynecology and Reproductive Biology, 139(1), 86-89.

Belsky, J., Steinberg, L., Houts, R. M., Halpern-Felsher, B. L., \& NICHD Early Child Care Research Network. (2010). The development of reproductive strategy in females: early maternal harshness -> earlier menarche -> increased sexual risk taking. Developmental Psychology, 46, 120-128.

Ben-Shlomo, Y. \& Kuh, D. (2002). A life course approach to chronic disease epidemiology: Conceptual models, empirical challenges and interdisciplinary perspectives. International Journal of Epidemiology, 31, 285-293. 
Boden, J. M., Fergusson, D. M., \& Horwood, L. J. (2011). Age of menarche and psychosocial outcomes in a New Zealand birth cohort. Journal of the American Academy of Child and Adolescent Psychiatry, 50, 132-140 e5.

Bodzsár É. B. (2000). Studies on sexual maturation of Hungarian children. Acta Biologica Szegediensis, 44(1-4), 155-165.

Bodzsár, É. B. \& Zsákai, A. (2002). Some aspects of secular changes in Hungary over the twentieth century. Collegium antropologicum, 26, 477-484.

Bodzsár, É. B. (1977). Újabb adatok a magyar leányok menarche-korához. Anthropológiai Közlemények, 21, 81-92.

Boncz, I., Sebestyén, A., Döbrössy, L., Kovács, A., Budai, A., \& Székely, T. (2007). A méhnyakszűrés részvételi mutatói Magyarországon. Orvosi Hetilap, 148, 2177-2182.

Bonjour, M. \& Vlugt, I. (2018). Comprehensive Sexuality Education. Rutgers, Utrecht https://www.rutgers.international/sites/rutgersorg/files/PDF/knowledgefiles/20181218_kn owledge\%20file_CSE.pdf Accessed: December 20, 2018

Borsos, A. (2016). A gyermeknőgyógyászat alapvonalai. In: Papp Z. (ed.): A nőgyógyászat kézikönyve. Medicina Könyvkiadó Zrt., Budapest, pp. 239-250.

Bősze, P. (2010). A méhnyaklaphám rákelőző állapota (cervicalis intraepithelialis neoplasia, CIN) (1. rész). Nögyógyászati Onkológia, 15,133-139.

Breuner, C. C., Mattson, G., \& COMMITTEE ON ADOLESCENCE, COMMITTEE ON PSYCHOSOCIAL ASPECTS OF CHILD AND FAMILY HEALTH. (2016). Sexuality Education for Children and Adolescents. Pediatrics, 138, e20161348. doi: 10.1542/peds.2016-1348. Epub 2016 Jul 18.

Brook, G., Bacon, L., Evans, C., McClean, H., Roberts, C., Tipple, C., Winter, A. J., \& Sullivan, A. K. (2014). 2013 UK national guideline for consultations requiring sexual history taking. Clinical Effectiveness Group British Association for Sexual Health and HIV. International Journal of STD \& AIDS, 25(6), 391-404. https://doi.org/10.1177/0956462413512807

Brotherton, J. M. L. (2017). Confirming cross-protection of bivalent HPV vaccine. The Lancet Infectious Diseases, 17(12), P1227-1228, https://doi.org/10.1016/S1473-3099(17)30539-X

Byrd, T. L., Peterson, S. K., Chavez, R., \& Heckert, A. (2004). Cervical cancer screening beliefs among young Hispanic women. Preventive Medicine, 38, 192-197.

Caddy, S., Yudin, M. H., Hakim, J., Money, D. M., \& INFECTIOUS DISEASE COMMITTEE; SPECIAL CONTRIBUTOR. (2014). Best practices to minimize risk of infection with intrauterine device insertion. Journal of Obstetrics and Gynaecology of Canada, 36(3), 266-274. doi: 10.1016/S1701-2163(15)30636-8.

Castle, P. E. (2008). How does tobacco smoke contribute to cervical carcinogenesis? Journal of virology, 82(12), 6084-6085.

Chandra-Mouli, M. B. B., Svanemyr, J., Amin, A., Fogstad, H., Say, L., Girard, F., \& Temmerman, M. (2015). Twenty Years After International Conference on Population and Development: Where Are We with Adolescent Sexual and Reproductive Health and Rights? Journal of Adolescent Health, 56, s1-s6. 
Chandra-Mouli, V., McCarraher, D. R., Phillips, S. J., Williamson, N. E., \& Hainsworth, G. (2014). Contraception for adolescents in low and middle income countries: needs, barriers, and access. Reproductive health, 11:1. doi:10.1186/1742-4755-11-1

Chodick, G., Huerta, M., Balicer, R. D., Davidovitch, N., \& Grotto, I. (2005). Secular trends in age at menarche, smoking, and oral contraceptive use among Israeli girls. Preventing $\begin{array}{llll}\text { Chronic Disease, } & \text { [serial online], }\end{array}$ http://www.cdc.gov/pcd/issues/2005/apr/pdf/04_0063.pdf Accessed: October 12, 2018.

Chumlea, W. C., Schubert, C. M., Roche, A. F., Kulin, H. E., Lee, P. A, Himes, J. H., \& Sun, S. S. (2003). Age at menarche and racial comparisons in US girls. Pediatrics. 111, 110 113.

Committee on Adolescence. (2014). Contraception for adolescents. Pediatrics. 134, e12441256. doi: 10.1542/peds.2014-2299.

Currie, C., Gabhainn, S. N., Godeau, E., Roberts, C., Smith, R., Currie, D., Picket, W., Richter, M., Morgan, A., \& Barnekow, V. (2008). Inequalities in young people's health. HBSC international report from the 2005/2006 Survey. Copenhagen, WHO Regional Office for Europe. (Health Policy for Children and Adolescents, No. 5), Section 4: Risk behaviour, pp. 113-166.

Currie, C., Zanotti, C., Morgan, A., Currie, D., Looze, M. D., \& Roberts, C. (2012). Social determinants of health and well-being among young people. Health Behaviour in Schoolaged Children (HBSC) study: international report from the 2009/2010 survey. Copenhagen, WHO Regional Office for Europe. (Health Policy for Children and Adolescents, No. 6). Chapter 5. Risk behaviours, pp. 139-201.

Curtis, K. M., Tepper, N. K., Jatlaoui, T. C., Berry-Bibee, E., Horton, L. G., Zapata, L. B., Simmons, K. B., Pagano, H. P., Jamieson, D. J., Whiteman, M. K. (2016). U.S. Medical Eligibility Criteria for Contraceptive Use, 2016. Morbidity and Mortality Weekly Report Recommendations and Reports. 65(RR-3), 1-104. DOI: http://dx.doi.org/10.15585/mmwr.rr6503a1

Dawar, M., Deeks, S., \& Dobson, S. (2007). Human papillomavirus vaccines launch a new era in cervical cancer prevention. CMAJ: Canadian Medical Association journal = journal de l'Association medicale canadienne, 177(5), 456-461.

Dehlendorf, C., Krajewski, C., \& Borrero, S. (2014). Contraceptive counseling: best practices to ensure quality communication and enable effective contraceptive use. Clinical Obstetrics and Gynecology, 57, 659-673. doi: 10.1097/GRF.0000000000000059.

Delisi, K. \& Gold M. A. (2008). The initial adolescent preventive care visit. Clinical Obstetrics and Gynecology, 51, 190-204.

Devosa, I., Kozinszky, Z., Vanya, M., Szilim K., Fayne Dombi, A., \& Barabas, K. (2016). Szegedi egyetemi hallgatók ismeretei a megbízható fogamzásgátlásról és a szexuális úton terjedő betegségekről. Orvosi Hetilap, 157, 539-546.

Diaz-Franco, E. C., Lira-Plascencia, J., Watty-Martinez, A., \& Acosta-Bourne, M. (2013). The pregnant adolescent: information, beliefs and attitudes toward sexuality. Ginecologia y Obstetricia de México, 81, 693-699. [Spanish] 
Diedrich, J. T., Klein, D. A., \& Peipert, J. F. (2017). Long-acting reversible contraception in adolescents: a systematic review and meta-analysis. American Journal of Obstetrics and Gynecology, 216, 364.e1-364.e12. doi: 10.1016/j.ajog.2016.12.024. Epub 2016 Dec 28.

Doktor, S. (1891). A hószámról. Orvosi Hetilap, 39, 478-494.

Donati, S., Medda, E., Spinelli, A., \& Grandolfo, M.E. (2000). Sex education in secondary schools: An Italian experience. Journal of Adolescent Health, 26, 303-308.

Doukrou, M. \& Segal, T. Y. (2018). Fifteen-minute consultation: Communicating with young people-how to use HEEADSSS, a psychosocial interview for adolescents. Archives of Disease in Childhood. Education and Practice Edition, 103, 15-19. doi: 10.1136/archdischild-2016-311553.

Downing, J. \& Bellis, M. A. (2009). Early pubertal onset and its relationship with sexual risk taking, substance use and anti-social behaviour: a preliminary cross-sectional study. $B M C$ Public Health, 9, 446.

Emberi Erőforrások Minisztériuma útmutatója a 2018. évi védőoltásokról. (2018). Egészségügyi Közlöny, 3, 312-344.

Fang, J. H., Yu, X. M., Zhang, S. H., \& Yang, Y. (2018). Effect of smoking on high-grade cervical cancer in women on the basis of human papillomavirus infection studies. Journal of Cancer Research and Therapeutics, 14, 184-189.

Fergus, S., Zimmerman, M. A. \& Caldwell, C. H. (2007). Growth Trajectories of Sexual Risk Behavior in Adolescence and Young Adulthood. American Journal of Public Health, 97, 1096-1101. doi:10.2105/AJPH.2005.074609.

Francis, J. K. R. \& Gold, M. A. (2017). Long-Acting Reversible Contraception for Adolescents: A Review. JAMA Pediatrics, 171, 694-701. doi: 10.1001/jamapediatrics.2017.0598.

Fülöp, V. (2010). A HPV-fertőzés és a HPV elleni vakcináció immunbiológiája. Gyermekorvos Továbbképzés, 9(5), 248-252.

Garçon, N., Morel, S., Didierlaurent, A., Descamps, D., Wettendorff, M., \& Van Mechelen. M. (2011). Development of an AS04-adjuvanted HPV vaccine with the adjuvant system approach. BioDrugs, 25(4), 217-226. doi: 10.2165/11591760-000000000-00000.

Gaudineau, A., Ehlinger, V., Vayssiere, C., Jouret, B., Arnaud, C., \& Godeau, E. (2010). Factors associated with early menarche: results from the French Health Behaviour in School-aged Children (HBSC) study. BMC Public Health, 10, 175.

Gellin, B., Modlin, J. F., Barr, E., \& Tamms T. (2007). Quadrivalent Human Papillomavirus Vaccine. Clinical Infectious Diseases, 45(5), 609-617. https://doi.org/10.1086/520654

Gemzell-Danielsson, K., Buhling, K. J., Dermout, S. M., Lukkari-Lax, E., Montegriffo, E., \& Apter, D. (2016). A Phase III, single-arm study of LNG-IUS 8, a low-dose levonorgestrel intrauterine contraceptive system (total content $13.5 \mathrm{mg}$ ) in postmenarcheal adolescents. Contraception, 93, 507-512. doi: 10.1016/j.contraception.2016.02.004. Epub 2016 Feb 9.

Gemzell-Danielsson, K., Inki, P., \& Heikinheimo, O. (2013). Safety and efficacy of the levonorgestrel-releasing intrauterine system: recent insights. Expert Review of Obstetrics \& Gynecology, 8, 235-247. DOI: 10.1586/eog.13.18 
Glynn, J. R., Kayuni, N., Floyd, S., Banda, E., Francis-Chizororo, M., Tanton, C., Molesworth, A., Hemmings, J., Crampin, A. C., \& French, N. (2010). Age at menarche, schooling, and sexual debut in northern Malawi. PLoS One. 5, e15334.

Godeau, E. E. A. (2011). A profile of young people's sexual behaviour: findings from the health behaviour in school-aged children study. Entre Nous, 72, 24-27.

Godeau, E., Vignes, C., Duclos, M., Navarro, F., Cayla, F., \& Grandjean, H. (2008). Factors associated with early sexual initiation in girls: French data from the international survey Health Behaviour in School-aged Children (HBSC)/WHO. Gynécologie, obstétrique \& fertilité, 36, 176-182 [French]

Halmai, R. \& Németh, Á. (2011). Dohányzási szokások. In: Németh, Á. \& Költő, A. (eds). Serdülökorú fiatalok egészsége és életmódja. Az Iskoláskorú gyermekek egészségmagatartása címü, az Egészségügyi Világszervezettel együttmüködésben zajló nemzetközi kutatás 2010. évi felméréséröl készült nemzeti jelentés. Országos Gyermekegészségügyi Intézet, Budapest, pp. 35-39.

Harper D. M. \& DeMars L. R. (2017). HPV vaccines - A review of the first decade. Gynecologic Oncology, 146, 196-204.

Hernandez, B. Y., Wilkens, L. R., Zhu, X., Thompson, P., McDuffie, K., Shvetsov, Y. B., Kamemoto, L. E., Killeen, J., Ning, L., \& Goodman, M. T. (2008). Transmission of human papillomavirus in heterosexual couples. Emerging infectious diseases, 14(6), 888-894.

Huff, M. B., McClanahan, K. K., Brown, H. A., \& Omar, H. A. (2009). It is more than just a reproductive health care visit: Experiences from an adolescent medicine clinic. International journal of adolescent medicine and health, 21, 243-248.

Ibitoye, M., Choi, C., Tai, H., Lee, G., \& Sommer, M. (2017). Early menarche: A systematic review of its effect on sexual and reproductive health in low- and middle-income countries. PLOS ONE, 12(6), e0178884. https://doi.org/10.1371/journal.pone.0178884

Inchley, J., Currie, D., Young, T., Samdal, O., Torsheim, T., Augustson, L., Mathison, F., Aleman-Diaz, A., Molcho, M., Weber, M., \& Barnekow, V. (eds.) (2016). Growing up unequal: gender and socioeconomic differences in young people's health and well-being. Health Behaviour in School-Aged Children (HBSC) Study: International report from the 2013/2014 survey. Copenhagen, WHO Regional Office for Europe. (Health Policy for Children and Adolescents, No. 7), Chapter 5. Risk behaviours, pp. 145-211.

International Planned Parenthood Federation. (2017). DELIVER+ENABLE TOOLKIT: $\begin{array}{llll}\text { Scaling-up comprehensive } & \text { sexuality } & \text { education }\end{array}$ https://www.ippf.org/sites/default/files/201803/IPPF\%20Deliver\%20and\%20Enable\%20-\%20CSE\%20Toolkit.pdf Accessed October, 2018

Jean, R. T., Wilkinson, A. V., Spitz, M. R., Prokhorov, A., Bondy, M., \& Forman, M.R. (2011). Psychosocial risk and correlates of early menarche in Mexican-American girls. American Journal of Epidemiology, 173, 1203-1210.

Jensen, K. E., Schmiedel, S., Norrild, B., Frederiksen, K., Iftner, T., \& Kjaer, S. K. (2012). Parity as a cofactor for high-grade cervical disease among women with persistent human 
papillomavirus infection: a 13-year follow-up. British Journal of Cancer, 108(1), 234-239. doi: $10.1038 /$ bjc. 2012.513

Jit, M., Chapman, R., Hughes, O., \& Choi H. Y. (2011). Comparing bivalent and quadrivalent human papillomavirus vaccines: economic evaluation based on transmission model. $B M J$, 343, d5775

Jubelirer, S. J., Blanton, M. F., Balnton, P. D., Zhang, J., \& Hanshew, D. (1996). Assessment of knowledge, attitudes, and behaviors relative to cervical cancer and the Pap smear among adolescent girls in West Virginia. Journal of Cancer Education, 11, 230-232.

Kaltiala-Heino, R., Koivisto, A. M., Marttunen, M., \& Frojd, S. (2011). Pubertal timing and substance use in middle adolescence: a 2-year follow-up study. Journal of Youth and Adolescence, 40, 1288-1301.

Kapamadzija, A., Vejnovic, T., Novakov Mikic, A., Vukelic, J., Kopitovic, V., \& Bjelica, A. (2010). Sexual knowledge, attitudes and practice of adolescents in Northern Serbia - Are we making any progress? Follow-up study 2000-2008. Journal für Reproduktionsmedizin und Endokrinologie, 7(Special Issue 1, 106-111.

Kaunitz, A. M. (2018) Contraceptive counseling and selection. https://www.uptodate.com/contents/contraceptive-counseling-and-selection This topic last updated: Sep 10, 2018. Accessed: October 12, 2018.

Kavanagh, K., Pollock, K. G., Cuschieri, K., Palmer, T., Cameron, R. L., Watt, C., Bhatia, R., Moore, C., Cubie, H., Cruickshank, M., \& Robertson R. (2017). Changes in the prevalence of human papillomavirus following a national bivalent human papillomavirus vaccination programme in Scotland: a 7-year cross-sectional study. The Lancet Infectious Diseases, 17(12), P1293-1302, http://dx.doi.org/10.1016/S1473-3099(17)30468-1

Kirby, D. \& Coyle, K. (1997). School-based programs to reduce sexual risk-taking behavior. Children and Youth Services Review, 19, 415-436. http://dx.doi.org/10.1016/S01907409(97)00025-X Accessed: October 12, 2018.

Knobler, S. L., O’Connor, S., Lemon, S. M., \& Najafi, M. (eds). (2004). The infectious etiology of chronic diseases. Defining the relationship, enhancing the research, and mitigating the effects. Workshop Summary. The National Academies Press, Washington, http://www.nap.edu/catalog/11026.html

Koiss, R., Boncz, I., Hernádi, Z., \& Szentirmay, Z. (2017). Javaslat a hazai méhnyakszürési eljárásrend korszerüsítésére. Orvosi Hetilap, 158, 2062-2067.

Kovács, A., Döbrössy, L., Budai, A., Boncz, I., \& Cornides, Á. (2007). A népegészségügyi méhnyakszürés helyzete Magyarországon. Orvosi Hetilap, 148(12), 535-540.

Kovacsics, L., Sebestyén, E., \& Németh, Á. (2007). Dohányzási szokások. In: Németh, Á. (ed). Serdülökorú fiatalok egészsége és életmódja. Az Iskoláskorú gyermekek egészségmagatartása elnevezésü, az Egészségügyi Világszervezettel együttmüködésben zajló nemzetközi kutatás 2006. évi felmérésének Nemzeti jelentése. Országos Gyermekegészségügyi Intézet, Budapest, pp. 75-80.

Költő, A. (2011). Szexuális magatartás. In: Németh, Á. \& Költő, A. (eds). Serdülőkorú fiatalok egészsége és életmódja. Az Iskoláskorú gyermekek egészségmagatartása címü, az 
Egészségügyi Világszervezettel együttmüködésben zajló nemzetközi kutatás 2010. évi felméréséről készült nemzeti jelentés. Országos Gyermekegészségügyi Intézet, Budapest, pp. 55-58.

Költő, A. (2016). Szexuális magatartás és romantikus tapasztalatok. In: Németh, Á. \& Költő, A. (eds.). Egészség és egészségmagatartás iskoláskorban 2014. Az Iskoláskorú gyermekek egészségmagatartása elnevezésü, az Egészségügyi Világszervezettel együttmüködésben megvalósuló nemzetközi kutatás 2014. évi felméréséröl készült nemzeti jelentés. Nemzeti Egészségfejlesztési Intézet, Budapest, pp. 121-130.

Központi Statisztikai Hivatal. (2012). Demográfiai évkönyv, 2011. Budapest

Központi Statisztikai Hivatal. (2017a). Demográfiai évkönyv, 2016. Budapest

Központi Statisztikai Hivatal. (2017b). Egészségügyi statisztikai évkönyv, 2016. Budapest

Központi Statisztikai Hivatal. (2018). Terhességmegszakitások.

www.ksh.hu/docs/hun/xftp/idoszaki/pdf/terhessegmegsz16.pdf (megjelenés: 2018.03.26.)

Lindberg, L., Santelli, J., \& Desai, S. (2016). Understanding the Decline in Adolescent Fertility in the United States, 2007-2012. Journal of Adolescent Health, 59, 577-583. doi: 10.1016/j.jadohealth.2016.06.024. Epub 2016 Aug 29.

Loeber, O., Reuter, S., Apter, D., van der Doef, S., Lazdane, G., \& Pinter, B. (2010). Aspects of sexuality education in Europe - definitions, differences and developments. European Journal of Contraception and Reproductive Health Care, 15, 169-176. doi:10.3109/13625181003797280.

Maaita, M. \& Brakat, M. (2002). Jordanian women's attitudes towards cervical cancer screening and cervical cancer. Journal of Obstetrics and Gynecology, 22, 421-422.

Major, T. (2014). Méhen belüli fogamzásgátlás még nem szült nőknél. A Szakmai Kollégium Szülészeti és Nőgyógyászati, Asszisztált Reprodukciós Tagozatának állásfoglalása. Magyar Nöorvosok Lapja, 77, 42-44.

Major, T. (2016). Fogamzásgátlás serdülőkorban. In: Papp Z. (ed.): A nőgyógyászat kézikönyve. Medicina Könyvkiadó Zrt, Budapest, pp. 260-264.

Marino, J. L., Skinner, S. R., Doherty, D. A., Rosenthal, S. L., Cooper Robbins, S.C., Cannon, J., \& Hickey, M. (2013). Age at menarche and age at first sexual intercourse: a prospective cohort study. Pediatrics, 132, 1028-1036.

Maxwell, C. J., Bancej, C. M., \& Snider, J. (2001). Factors important in promoting cervical cancer screening among Canadian women: Findings from the 1996-97 National Population Health Survey (NPHS). Canadian Journal of Public Health, 92, 127- 133.

McFadyen, J. (2004). Teaching sex education: Are Scottish school nurses prepared for the challenge? Nurse Education Today, 24, 113-120.

Mestad, R., Secura, G., Allsworth, J. E., Madden, T., Zhao, Q., \& Peipert, J. F. (2011). Acceptance of long-acting reversible contraceptive methods by adolescent participants in the Contraceptive CHOICE Project. Contraception, 84, 493-498. doi: 10.1016/j.contraception.2011.03.001. Epub 2011 Apr 27.

Nelms, B. C. (2003). Adolescent sex education: Making it a priority. Journal of Pediatric Health Care, 17, 221-222. 
Nwankwo, K. C., Aniebue, U. U., Aguwa, E. N., Anarado, A. N., \& Agunwah, E. (2011). Knowledge, attitudes and practices of cervical cancer screening among urban and rural Nigerian women: A call for education and mass screening. European Journal of Cancer Care, 20, 362-367.

OECD. (2009). Health at a Glance 2009: OECD Indicators. OECD Publishing. Doi:10.1787/health_glance-2009-en Accessed on 3 April 2011

OECD/EU. (2016). Health at a Glance: Europe 2016 - State of Health in the EU Cycle. OECD Publishing, Paris. http://dx.doi.org/10.1787/9789264265592-en

O'neil-Callahan, M., Peipert, J. F., Zhao, Q., Madden, T., \& Secura, G. (2013). Twenty-fourmonth continuation of reversible contraception. Obstetrics \& Gynecology, 122, 1083-1091. doi: 10.1097/AOG.0b013e3182a91f45.

Országos Epidemiológiai Központ. (2015). Védőoltások teljesítése, 2014. Epinfo, 22(33-34), 391-405.

Országos Epidemiológiai Központ. (2016). Védőoltások teljesítése, 2015. Epinfo, 23(31), 369381.

Papp, Z. \& Csapó, Z. (2009). A női nemi szervek jó- és rosszindulatú daganatai (nőgyógyászati onkológia). In: Papp Z (ed.). A szülészet-nögyógyászat tankönyve. Budapest, Semmelweis Kiadó, p. 486.

Papp, Z. (2017). A szülészet-nőgyógyászat tankönyve. Budapest, Semmelweis Kiadó és Multimédia Stúdió

Paz-Soldán, V. A., Nussbaum, L., Bayer, A. M., \& Cabrera, L. (2010). Low knowledge of cervical cancer and cervical Pap smears among women in Peru, and their ideas of how this could be improved. International Quarterly of Community Health Education, 31, 245-263.

Pénzes, M., Czeglédi, E., Balázs, P., \& Urbán, R. (2017). Dohányzói életutak magyar serdülők körében. Orvosi Hetilap, 158, 67-76.

Pete, I. (2011). HPV-fertőzés, vakcina, keresztvédelem. Onkológia/Oncology, 74(1), 2-6.

Póka, R. (2018). Méhnyakszürés. Nemzetközi körkép és javaslat a hazai irányelvek fejlesztésére. Magyar Nöorvosok Lapja, 81, 38-46.

Poulin, C. \& Graham, L. (2001). The association between substance use, unplanned sexual intercourse and other sexual behaviours among adolescent students. Addiction, 96, 607621.

Pound P., Denford S., Shucksmith J., Tanton C., Johnson A.M., Owen J., Hutten R., Mohan L., Bonell C., Abraham C., \& Campbell R. (2017). What is best practice in sex and relationship education? A synthesis of evidence, including stakeholders' views. British Medical Journal Open. 2017 Jul 2; 7(5): e014791. doi: 10.1136/bmjopen-2016-014791. http://bmjopen.bmj.com/content/bmjopen/7/5/e014791.full.pdf.

Pritt, N. M., Norris, A. H., \& Berlan, E. D. (2017). Barriers and Facilitators to Adolescents' Use of Long-Acting Reversible Contraceptives. Journal of Pediatric and Adolescent Gynecology, 30, 18-22. doi: 10.1016/j.jpag.2016.07.002. Epub 2016 Jul 28. 
Rada, C. (2014). Sexual behaviour and sexual and reproductive health education: a crosssectional study in Romania. Reproductive Health, 11, 48 http://www.reproductive-healthjournal.com/content/11/1/48.

Raidoo, S. \& Kaneshiro, B. (2017). Contraception counseling for adolescents. Current Opinion in Obstetrics and Gynecology, 29, 310-315. doi: 10.1097/GCO.0000000000000390.

Schauner, S. \& Lyon, C. (2010). Bivalent HPV Recombinant Vaccine (Cervarix) for the Prevention of Cervical Cancer. American Family Physician, 82(12), 1541-1547.

Sedgh, G., Finer, L. B., Bankole, A., Eilers, M. A., \& Singh, S. (2015). Adolescent pregnancy, birth, and abortion rates across countries: levels and recent trends. Journal of Adolescent Health, 56(2), 223-230.

Sedgh, G., Henshaw, S. K., Singh, S., Bankole, A., \& Drescher, J. (2007). Legal abortion worldwide: Incidence and recent trends. International Family Planning Perspectives, 33, $106-116$.

Semsey, G. (2016). Szexuális nevelés a magyar gimnáziumokban - ahogy a diákok látják. In: Karlovitz, J. T. (ed.): Társadalom, kulturális háttér, gazdaság, 2016, International Research Institute s.r.o. Komárno, pp. 331-339. ISBN 978-80-89691-33-3 http://www.irisro.org/tarstud2016aprilis/69SemseyGabor.pdf

Shafii, T. \& Burstein, G. R. (2009). The adolescent sexual health visit. Obstetrics and Gynecology Clinics of North America, 36, 99-117.

Shand, L., Burney, S., \& Fletcher, J. (2010). Knowledge of cervical cancer, Pap testing and the human papillomavirus among young Australian women. Health Promotion Journal of Australia, 21, 202-207.

Sieving, R. E., Oliphant, J. A., \& Blum, R. (2002). Adolescent sexual behavior and sexual health. Pediatrics in Review, 23, 407-416.

Sigurdsson, K. \& Sigvaldason, H. (2007). Is it rational to start population-based cervical cancer screening at or soon after age 20? Analysis of time trends in preinvasive and invasive diseases. European Journal of Cancer, 43(4), 769-774.

Simich R. (2010). Iskola - egészségfejlesztés - szexedukáció. Veszélyeztetett korú diákok prevenciós igényei és szükségletei. Országos Egészségfejlesztési Intézet, http://regi.oefi.hu/tanulmany_szex.pdf Accessed: October 20, 2018

Sober, S., Shea, J. A., Shaber, A. G., Whittaker, P.G., \& Schreiber, C. A. (2017). Postpartum adolescents' contraceptive counselling preferences. European Journal of Contraception and Reproductive Health Care, 22, 83-87. doi: 10.1080/13625187.2016.1269161. Epub 2017 Jan 6.

Society for Adolescent Health and Medicine, Burke, P. J., Coles, M. S., Di Meglio, G., Gibson, E. J., Handschin, S. M., Lau, M., Marcell, A. V., Tebb, K. P., \& Urbach, K. (2014). Sexual and reproductive health care: a position paper of the Society for Adolescent Health and Medicine. Journal of Adolescent Health, 54, 491-496. doi: 10.1016/j.jadohealth.2014.01.010.

Society for Adolescent Health and Medicine. (2017). Abstinence-Only-Until-Marriage Policies and Programs: An Updated Position Paper of the Society for Adolescent Health 
and Medicine. Journal of Adolescent Health, 61, 400-403. doi:10.1016/j.jadohealth.2017.06.001.

Stephenson, J. M., Strange, V. F., Forrest, S. Oakley, A., Copas, A., Allen, E., Babiker, A., Black, S., Ali, M., Monteiro, H., Johnson, A. M., \& RIPPLE study team. (2004). Pupil-led sex education in England (RIPPLE study): Cluster-randomized intervention trial. Lancet, 364, 338- 346.

Sufrin, C. B., Postlethwaite, D., Armstrong, M. A., Merchant, M., Wendt, J. M., \& Steinauer, J. E. (2012). Neisseria gonorrhoea and Chlamydia trachomatis screening at intrauterine device insertion and pelvic inflammatory disease. Obstetrics \& Gynecology, 120, 1314 1321. doi: http://10.1097/AOG.0b013e318273364c.

Sulak, P. J., Herbelin, S. J., Fix, D. D. A., \& Kuehl, T. J. (2006). Impact of an adolescent sex education program that was implemented by an academic medical center. American Journal of Obstetrics and Gynecology, 195, 78-84.

Svanemyr, J., Amin, A., Robles, O., \& Greene, M. (2015). Creating an Enabling Environment for Adolescent Sexual and Reproductive Health: A Framework and Promising Approaches. Journal of Adolescent Health, 56, s7-s14.

Taberna, M., Mena, M., Pavón, M. A., Alemany, L., Gillison, M. L., \& Mesía, R. (2017). Human papillomavirus-related oropharyngeal cancer. Annals of Oncology, 28(10), 23862398. doi: 10.1093/annonc/mdx304.

Tekgül, N., Saltik, D., \& Vatansever, K. (2014). Secular trend of menarche age in an immigrant urban city in Turkey: Izmir. Turkish Journal of Pediatrics, 56, 138-43.

Thaxton, L. \& Espey, E. (2017). Family Planning American Style Redux: Unintended Pregnancy Improves, Barriers Remain. Obstetrics and Gynecology Clinics of North America, 44, 41-56. doi: 10.1016/j.ogc.2016.11.001.

Todorova, I., Baban, A., Alexandrova-Karamanova, A., \& Bradley, J. (2009). Inequalities in cervical cancer screening in Eastern Europe: Perspectives from Bulgaria and Romania. International Journal of Public Health, 54, 222-232.

Tomlin, K., Bambulas, T., Sutton, M., Pazdernik, V., \& Coonrod, D. V. (2017). Motivational Interviewing to Promote Long-Acting Reversible Contraception in Postpartum Teenagers. Journal of Pediatric and Adolescent Gynecology, 30, 383-388. doi: 10.1016/j.jpag.2016.11.001. Epub 2016 Nov 18.

United Nations Educational, Scientific and Cultural Organization. (2018). International technical guidance on sexuality education. An evidence-informed approach. Revised edition. UNESCO's ISBN 978-92-3-100259-5 www.unaids.org/sites/default/files/media_asset/ITGSE_en.pdf_Accessed November 20, 2018

Vajda, R., Árváné Egri, Cs., Kovács, A., Budai, A., Döbrőssy, L., Koiss, R., Kívés, Zs., \& Boncz, I. (2017a). A védőnői méhnyakszürési pilot program értékelése. Orvosi Hetilap, 158(12), 461-467. 
Vajda, R., Árváné Egri, Cs., Kovács, A., Budai, A., Döbrőssy, L., Koiss, R., Kívés, Zs., \& Boncz, I. (2017b). A védőnői méhnyakszürési pilotprogram minőségi indikátorai és teljesítménymutatói. Magyar Onkológia, 61, 361-367.

Varga-Tóth, A. \& Paulik, E. (2015). Role of gynecologists in reproductive education of adolescent girls in Hungary. Journal of Obstetrics and Gynaecology Research, 41, 747754. doi: 10.1111/jog. 12629.

Várnai, D. \& Németh, Á. (2007). Szexuális magatartás. In: Németh, Á. (ed). Serdülökorú fiatalok egészsége és életmódja. Az Iskoláskorú gyermekek egészségmagatartása elnevezésü, az Egészségügyi Világszervezettel együttmüködésben zajló nemzetközi kutatás 2006. évi felmérésének Nemzeti jelentése. Országos Gyermekegészségügyi Intézet, Budapest, pp. 99-102.

Wattigney, W. A., Srinivasan, S. R., Chen, W., Greenlund, K. J., \& Berenson, G. S. (1999). Secular trend of earlier onset of menarche with increasing obesity in black and white girls: the Bogalusa Heart Study. Ethnicity \& Disease, 9, 181-189.

Wellings, K., Collumbien, M., Slaymaker, E., Singh, S., Hodges, Z., Patel, D., \& Bajos, N. (2006). Sexual behaviour in context: a global perspective. Lancet, 368, 1706-1728.

WHO Regional Office for Europe and BZgA. (2010). Standards for Sexuality Education in Europe. A framework for policy makers, educational and health authorities and specialists.

Federal Centre for Health Education, BZgA, Cologne, https://www.bzgawhocc.de/fileadmin/user_upload/WHO_BZgA_Standards_English.pdf Accessed: December 20, 2018. [Hungarian version: http://www.szexualpszichologia.hu/who_iranyelvei.html_Accessed: 20 December 2018]

Wight, D., Raab, G. M., Henderson, M., Abraham, C., Buston, K., Hart, G., \& Scott, S. (2002). Limits of teacher delivered sex education: interim behavioural outcomes from randomised trial. BMJ (Clinical research ed.), 324(7351), 1430.

World Health Organization (2015). Medical eligibility criteria for contraceptive use. Fifth edition, http://apps.who.int/iris/bitstream/10665/181468/1/9789241549158_eng.pdf Accessed: October 20, 2018

World Health Organization International Agency for Research on Cancer. (1995). IARC Monographs on the Evaluation of Carcinogenic Risks to Humans. Volume 64 Human Papillomaviruses. IARC, Lyon, France

World Health Organization International Agency for Research on Cancer. (2007). IARC Monographs on the Evaluation of Carcinogenic Risks to Humans. Volume 90 Human Papillomaviruses. IARC, Lyon, France

Yang, D. Y., \& Bracken, K. (2016). Update on the new 9-valent vaccine for human papillomavirus prevention. Canadian family physician Medecin de famille canadien, 62(5), 399-402. 


\section{Acknowledgements}

I would like to thank to Professor Dr. László Nagymajtényi for the opportunity to prepare my thesis in the Doctoral School of Interdisciplinary Medicine.

I would like to give expression to my gratitude for Dr. Edit Paulik, my supervisor for her scientific guidance and consultative support throughout the whole research work.

I express my sincere gratitude to Professor Dr. Attila Pál for raising my interest in scientific research and providing facilities to accomplish my thesis.

My special thanks to Professor Dr. Gábor Németh for his personal guidance and advices related to my scientific work.

I am grateful to Professor Dr. László Kovács for his advices and support related to the scientific papers.

I also thank to my colleagues, my assistant of the Department of Obstetrics and Gynecology and the staff of the Department of Public Health for their contribution.

I am especially thankful to my family for their patience and help during my work. 